\title{
Patient prioritization for pharmaceutical care in hospital: A systematic review of assessment tools
}

DOI:

10.1016/j.sapharm.2018.09.009

\section{Document Version}

Accepted author manuscript

Link to publication record in Manchester Research Explorer

\section{Citation for published version (APA):}

Alshakrah, M., Steinke, D., \& Lewis, P. (2018). Patient prioritization for pharmaceutical care in hospital: A systematic review of assessment tools. Research in Social and Administrative Pharmacy.

https://doi.org/10.1016/j.sapharm.2018.09.009

\section{Published in:}

Research in Social and Administrative Pharmacy

\section{Citing this paper}

Please note that where the full-text provided on Manchester Research Explorer is the Author Accepted Manuscript or Proof version this may differ from the final Published version. If citing, it is advised that you check and use the publisher's definitive version.

\section{General rights}

Copyright and moral rights for the publications made accessible in the Research Explorer are retained by the authors and/or other copyright owners and it is a condition of accessing publications that users recognise and abide by the legal requirements associated with these rights.

\section{Takedown policy}

If you believe that this document breaches copyright please refer to the University of Manchester's Takedown Procedures [http://man.ac.uk/04Y6Bo] or contact uml.scholarlycommunications@manchester.ac.uk providing relevant details, so we can investigate your claim.

\section{OPEN ACCESS}




\section{Accepted Manuscript}

Patient prioritization for pharmaceutical care in hospital: A systematic review of assessment tools

Meshal A. Alshakrah, Douglas T. Steinke, Penny J. Lewis

PII:

S1551-7411(18)30410-8

DOI:

10.1016/j.sapharm.2018.09.009

Reference: RSAP 1136

To appear in: Research in Social \& Administrative Pharmacy

Received Date: 18 May 2018

Revised Date: 18 September 2018

Accepted Date: 18 September 2018

Please cite this article as: Alshakrah MA, Steinke DT, Lewis PJ, Patient prioritization for pharmaceutical care in hospital: A systematic review of assessment tools, Research in Social \& Administrative Pharmacy (2018), doi: https://doi.org/10.1016/j.sapharm.2018.09.009.

This is a PDF file of an unedited manuscript that has been accepted for publication. As a service to our customers we are providing this early version of the manuscript. The manuscript will undergo copyediting, typesetting, and review of the resulting proof before it is published in its final form. Please note that during the production process errors may be discovered which could affect the content, and all legal disclaimers that apply to the journal pertain. 
Patient prioritization for pharmaceutical care in hospital: a systematic review of assessment tools ${ }^{1}$

Meshal A. Alshakrah*, Douglas T. Steinke, Penny J. Lewis

Division of Pharmacy and Optometry, Faculty of Biology, Medicine and Health, University of Manchester, Stopford Building, Oxford Road, Manchester, M13 9PT, United Kingdom

\section{*Corresponding author}

Meshal A. Alshakrah

Division of Pharmacy and Optometry, Faculty of Biology, Medicine and Health, University of Manchester, Stopford Building, Oxford Road, Manchester, M13 9PT, United Kingdom Email: meshal.alshakrah@ postgrad.manchester.ac.uk

\section{Co-author Email addresses:}

Douglas.steinke@manchester.ac.uk

Penny.Lewis@manchester.ac.uk

\section{Declaration of interest:}

None

\footnotetext{
Abbreviations

Drug-related problems (DRPs); medication errors (MEs); adverse drug events (ADEs); adverse drug reactions (ADRs); pharmaceutical assessment screening tool (PAST); Assessment Risk Tool (ART)
} 


\section{Funding:}

This systematic review is part of $\mathrm{PhD}$ thesis that is funded by the Ministry of Higher Education (Saudi Arabia).

Role of the funding source: The funding Source had no role in study design; in the collection, analysis and interpretation of data; in the writing of the report; and in the decision to submit the article for publication.

\section{Acknowledgements:}

None 


\section{Patient prioritization for pharmaceutical care in hospital: A systematic review of} assessment tools

\section{Abstract}

5 Background: Clinical pharmacy services improve patient safety, outcomes, and care quality;

6 however, UK clinical pharmacy services face limited resources, insufficient capacity, and

7 patients who present with increasingly complex medication regimes and morbidities. These

8 indicate a need for the prioritization of pharmacy services. Several prioritization tools have

9 been developed; however, there has been no comprehensive review of such tools to date.

10 Objective: A systematic review was conducted to provide a structured overview and 11 description of existing assessment tools with a focus on study quality, themes, tool validity, 12 risk factors, and high-risk drug classes.

13 Methods: Systematic searches for English-language publications (from 1990 to September 14 2017) were conducted in Embase, Medline, Scopus, International Pharmaceutical Abstracts, 15 and Web of Science. Papers in the inpatient setting and in which the tool users were 16 pharmacists or pharmacy technicians were included. Data on each study (e.g. aim and design) and the structure of tools (e.g. risk factors) from each included study were extracted by 2 independent reviewers. A descriptive analysis was conducted to summarize these tools along with a thematic analysis of study findings. The quality of each paper was assessed using the

20 Hawker method.

21 Results: Nineteen studies involving 17 risk assessment tools were included. Most tools were 22 developed in Europe (76.5\%) and published in the last 5 years (82\%). Most tools (88\%) were designed to identify patients at greatest risk of adverse drug reactions, adverse drug events, or medication errors and to guide appropriate pharmaceutical care. Ten out of 17 tools (59\%) were validated. None showed a measurable impact on prescription errors or adverse drug 
events. Keys themes identified from the studies were the positive impact of risk assessment tools on both patient care and provision of pharmacy services as well as the limitations of risk assessment tools.

Conclusions: Current assessment tools are heterogeneous in their content, targeting diverse patient groups and clinical settings making generalization difficult. However, an underlying theme of all studies was that tools appear to achieve their aim in directing pharmaceutical care to where it is needed most which might provide reassurance and incentive for greater adoption and development of tools across clinical pharmacy services. However, further research is required to measure objectively the impact of tools on patient outcomes and on workforce efficiency so that comparisons can be made between tools.

Keywords: pharmacy prioritization, patient safety, care quality, risk assessment, patient priority, assessment tool

\section{Introduction}

40 Drug-related problems (DRPs) are a major concern for policymakers and practitioners in 41 healthcare systems globally. They place a substantial health and economic burden on both the 42 patient and healthcare system. ${ }^{1-4}$ DRPs could account for about $28 \%$ of patient visits to the emergency department. ${ }^{5}$ The rate of medication related hospitalization ranges from between 2 to $5.6 \%{ }^{6,7}$ Despite this, many DRPs can be prevented, thus reducing the length of hospital stays, associated costs, as well as morbidity and mortality. ${ }^{8,9}$ Interventions to identify and minimize DRPs have key clinical significance in instituting prompt and effective therapeutic interventions. $^{10}$

Clinical pharmacy services can be defined as the pharmacist led services that contribute actively to patient care in order to optimize drug therapy outcomes, these might include but are not limited to patient education, adjustment or monitoring of medication and reviews of 
51 medication charts. ${ }^{11,12}$ There is evidence to suggest that clinical pharmacy services improve

52 patient safety ${ }^{12,13}$ and that clinical pharmacists are major contributors to the identification,

53 rectification, and prevention of DRPs ${ }^{14}$ which can decrease the length of hospital stays. ${ }^{12}$

54 Ideally, each hospital pharmacy would have the resources to provide comprehensive clinical

55 pharmacy services to every patient based on their needs. ${ }^{15}$ However, pharmacy departments

56 are faced with numerous challenges, such as reduced funding, staffing issues, which are

57 combined with an increasing number of elderly admissions with multimorbidities and

58 polypharmacy, and a demand for a 7-day clinical services. ${ }^{15-22}$ This has led to more

59 innovative approaches to service delivery, which means that comprehensive clinical

60 pharmacy services are not provided to all patients. ${ }^{15,17,21,23,24}$ Prioritization of clinical

61 pharmacy services has been identified as one of the solutions for achieving cost effectiveness

62 and increased productivity. ${ }^{15,17,19,22-24}$ Therefore, there is a necessity to assess and prioritize

63 patients who are in most need of input from the pharmacist. This approach would improve

64 the delivery of clinical pharmacy services within a resource-limited healthcare service with

65 the aim of enhancing patient care. ${ }^{21}$

66 For the early detection and prompt management of high-risk patients in clinical settings,

67 several risk assessment tools have been developed. Several such tools exist in pharmacies and

68 help with the assessment of patient acuity, which is defined as the ability to predict patient

69 requirements for care. ${ }^{25}$ These tools differ from each other concerning the target patient

70 group (e.g., pediatrics, adult), address diverse sources of DRPs, and the setting that they were

71 developed for (e.g., primary or secondary care).

72 Despite the existence of multiple tools, a comprehensive review of these instruments has yet

73 to be undertaken. Therefore, a systematic review was conducted to provide a structured

74 overview and description of existing assessment tools used by hospital pharmacies that assess

75 patient priority and/or complexity with a focus on study quality, themes, tool validity, risk 
76 factors, and high-risk drug classes. The findings of a review of current approaches to

77 prioritization may be useful to both pharmacists and researchers who may want to compare

78 the tools and findings or design a new tool for local needs in daily practice.

79 Methods

$80 \quad$ Literature search

81 This review follows PRISMA Guidelines for reporting systematic reviews. ${ }^{26}$ Medline,

82 Embase, International Pharmaceutical Abstracts, Scopus, and Web of Science electronic

83 databases were used in the search from January 1990 to September 2017. The reference lists

84 of all included studies were also searched manually. The search involved the use of

85 synonyms, truncation symbols, such as an asterisk $\left(^{*}\right)$, as well as Boolean terms "OR" and

86 "AND," which made the search more general or more specific, respectively. Four

87 keywords - priority, tool, hospital, and pharmaceutical care-were used to start the search

88 (Table 1). The keywords and their synonyms together with the Boolean operators "AND" and

89 "OR" were used to obtain the articles. After the database search was complete, all duplicate

90 citations were removed using Mendeley reference management software (Elsevier, 2017).

91 Following this, the reviewer (MA) assessed publications for eligibility by title, abstract, or

92 full text screening. Any article for which there was uncertainty regarding inclusion or

93 exclusion was discussed between 3 authors (MA, DS, and PL) until agreement was reached.

94 Table 1: Search keywords

\section{Search Keywords}

\begin{tabular}{cc}
\hline 1. Priority & OR \\
& priorit*, triage*, acuity, \\
complex*.
\end{tabular}

2. Tool

OR

tool*, scor*, screen*, criteria,

scale, classif*, assess*, clinical 
assess* tool*, instrument*, $^{*}$ measure*, stratif*, software.

3. Hospital OR hospital*, secondary care.

\section{Pharmaceutical care}

OR pharmacy, pharmacist*,

pharmaceutical, pharmac*

service*, hospital pharmac*,

clinical pharmac*, clinical

pharmac* service*

\section{1 AND 2 AND 3 AND 4}

95

\section{Inclusion criteria}

97 Studies where the tool users were pharmacists or pharmacy technicians were included. All the studies published since that date until the date of the search (updated on November 30,

106 2017) were included in the review.

\section{Exclusion criteria}

108 Papers written in languages other than English were excluded because analyzing and 109 describing the tools required a complete understanding of the text. 


\section{Data extraction and quality assessment}

111 To achieve consistency, reduce bias, and ensure the extracted data were valid, standardized

112 data extraction forms were developed and used. The data extracted from the studies included

113 the author, the country, study aim, design, duration, sample size, population group, tool type,

114 tool benefits, tool limitations, study limitations, and tool validity. For each study, data were

115 extracted by 2 of the authors independently (MA and PL), with any disagreements in

116 extraction being resolved by discussion between all authors (MA, DS, and PL)).

117 A thematic analysis was conducted with data collected from the included articles.

118 Overarching themes were iteratively and inductively identified using the following steps: the

119 articles were read to gain familiarization and understanding of their content. ${ }^{27}$ Following this,

120 a list of key ideas was generated and grouped; these were then coded in the articles using

121 distinct colored highlighters to indicate potential patterns. Codes were grouped together into

122 categories. The initial codes and categories were reviewed and agreed by the authors, after

123 which they were applied in each included paper. Before the data were entered into the

124 framework matrix using an Excel spreadsheet, the data had been summarized. Once all the

125 data were coded, the codes were sorted into the overarching themes. Finally, the identified

126 themes were collated and analyzed to interpret the underlying meanings, which were labelled

127 as subthemes. The thematic analysis was performed by two authors (MA and PL). During all

128 stages there were repeated discussions between all authors (MA, DS, and PL) of the overall

129 interpretation of the data.

131 The quality of included papers was assessed by MA using the quality assessment tool by

132 Hawker and colleagues. ${ }^{28}$ It is considered appropriate for use in this review because it

133 appraises disparate publication papers, accounting for qualitative, quantitative, review

134 articles, and conference abstracts. In addition, it is more consistent to use this checklist, as 
135 opposed to individual checklists for each type of study. Furthermore, the 9-item checklist

136 allows the researcher to quantify and score results, thus enabling comparison of quality

137 between publication papers to identify areas that are weak/strong.

138 Hawker's assessment tool includes 9 questions with 4 criteria: good, fair, poor, and very

139 poor. Having applied the tool to the reviewed studies, a number was assigned to each section

140 of the included studies as follows: 4 for good, 3 for fair, 2 for poor, and 1 for very poor. This

141 produced a score for each study that ranged from 9 to 36 . Hawker and colleagues do not

142 suggest any limits for categorizing the sum quality rankings of the article. ${ }^{28}$ However,

143 previous studies ${ }^{29,30}$ have divided categories into high quality, medium quality and low

144 quality. This stratification of quality has been adapted to the current review and the

145 descriptors for the overall quality were also provided with the ranges in the score: 9-23

146 points for low quality (C), 24-29 points for medium quality (B), and 30-36 points for high

147 quality (A). The summary of the quality assessment is supplied in appendix B. 
149 Results

150 Overall, 14,937 articles were retrieved: Medline $(n=600)$, Embase $(n=6369)$, International

151 Pharmaceutical Abstracts $(n=618)$, Scopus $(n=6,266)$, and Web of Science $(n=1,084)$. Of

152 these, 5,683 were removed because of repetition and 9,239 were removed for irrelevance.

153 After reviewing the titles, abstracts, and full texts, fifteen publications were identified as

154 being relevant. A further manual search of the reference lists of retrieved articles led to the

155 identification of 4 additional articles. Therefore, the reviewers agreed on a final selection of

15619 publications for inclusion. A flow chart of this process is presented in Figure 1.

157

158 Nineteen studies (shown in Table 2) evaluated 17 scoring tools for assessing the risk of DRPs

159 and prioritizing the need for pharmaceutical care for patients at the greatest risk of DRPs. All

160 scoring tools were developed by pharmacists and relied on their knowledge and expertise. In

161 other words, all tools were designed by those that would use them. 
163 Table 2: A summary of the studies related to the pharmacy risk assessment tools

\begin{tabular}{|c|c|c|c|c|c|c|c|c|c|c|c|c|c|}
\hline \multirow{2}{*}{$\begin{array}{c}\text { Reference } \\
\text { year }\end{array}$} & \multirow[t]{2}{*}{ Country } & \multirow[t]{2}{*}{ Study aim } & \multirow{2}{*}{$\begin{array}{l}\text { Study } \\
\text { design }\end{array}$} & \multirow{2}{*}{$\begin{array}{c}\text { Study } \\
\text { duration }\end{array}$} & \multirow[t]{2}{*}{ Sample size } & \multirow{2}{*}{$\begin{array}{c}\text { Population } \\
\text { group }\end{array}$} & \multicolumn{2}{|c|}{ Tool } & \multicolumn{2}{|c|}{ Perceived tool benefits } & \multirow[t]{2}{*}{ Tool limitations } & \multirow[t]{2}{*}{ Study limitations } & \multirow{2}{*}{$\begin{array}{c}\text { Tool } \\
\text { validity }\end{array}$} \\
\hline & & & & & & & Type & Used & Patient care & Pharmacy services & & & \\
\hline $\begin{array}{l}\text { Carlson and } \\
\text { Phelps }(2015)^{31}\end{array}$ & U.S. & $\begin{array}{l}\text { To describe an } \\
\text { electronic clinical } \\
\text { scoring system to } \\
\text { prioritize patient } \\
\text { medication } \\
\text { monitoring }\end{array}$ & $\begin{array}{c}\text { Descriptive } \\
\text { article }\end{array}$ & NR & NR & $\begin{array}{l}\text { In-patients } \\
\text { pediatric and } \\
\text { adult patients }\end{array}$ & $\mathrm{E}$ & $\mathrm{Ph}$ & $\begin{array}{l}\text { Enables the } \\
\text { identification of } \\
\text { patients who } \\
\text { could benefit from } \\
\text { detailed MedRec }\end{array}$ & $\begin{array}{l}\text { Improves } \\
\text { pharmacists' } \\
\text { efficiency } \\
\text { allowing them to } \\
\text { focus their time } \\
\text { on high acuity } \\
\text { patients }\end{array}$ & NR & Review article & NR \\
\hline $\begin{array}{l}\text { Cottrell et al. } \\
(2013)^{32}\end{array}$ & U.K. & $\begin{array}{l}\text { To develop a tool } \\
\text { to identify patients } \\
\text { at greatest risk of } \\
\text { harm of } \\
\text { medication } \\
\text { incidents using } \\
\text { real time } \\
\text { prescribing } \\
\text { information from } \\
\text { HEPMA }\end{array}$ & $\begin{array}{l}\text { Prospective } \\
\text { cohort } \\
\text { study }\end{array}$ & $\begin{array}{l}\text { Apr-Oct } \\
2009 \\
\text { Apr-Oct } \\
2011\end{array}$ & $\begin{array}{l}\text { Fifteen } \\
\text { patients, } 5 \\
\text { from each } \\
\text { risk } \\
\text { category } \\
\text { (low, } \\
\text { medium, } \\
\text { and high) }\end{array}$ & In-patients & $\mathrm{E}$ & $\mathrm{Ph}$ & $\begin{array}{l}\text { Helps to provide } \\
\text { safe, effective, } \\
\text { and patient } \\
\text { centered care. }\end{array}$ & $\begin{array}{l}\text { It has a positive } \\
\text { impact on the } \\
\text { timely provision } \\
\text { of pharmaceutical } \\
\text { care to high-risk } \\
\text { patients }\end{array}$ & $\begin{array}{l}\text { Does not currently } \\
\text { incorporate data } \\
\text { from laboratory } \\
\text { and other clinical } \\
\text { systems; } \\
\text { Does not capture } \\
\text { co-morbidities } \\
\text { and deranged } \\
\text { blood results }\end{array}$ & 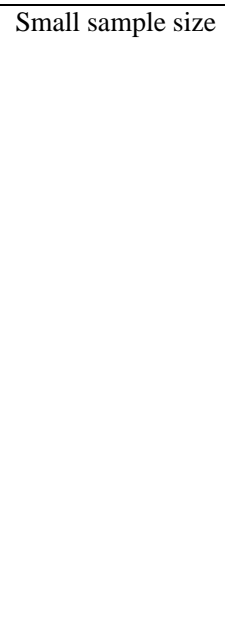 & $\begin{array}{c}\text { Validated } \\
\text { tool }\end{array}$ \\
\hline
\end{tabular}




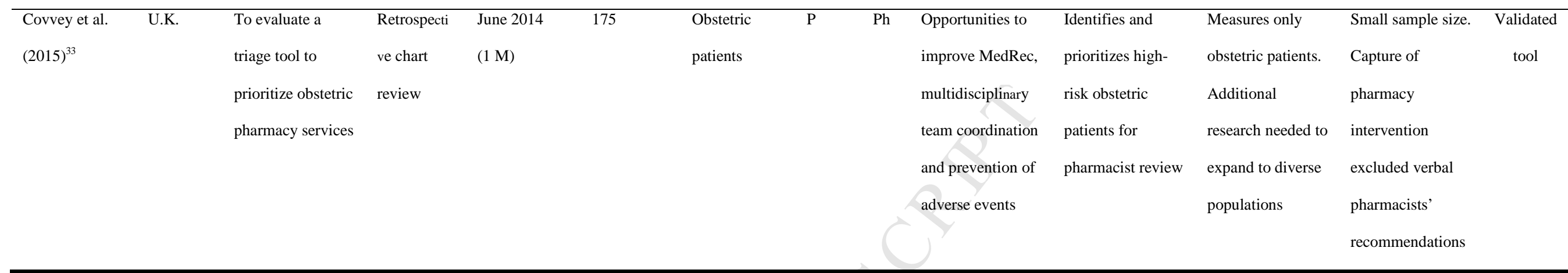

164

165 Table 2: Continued

\begin{tabular}{|c|c|c|c|c|c|c|c|c|c|c|c|c|c|}
\hline \multirow{2}{*}{$\begin{array}{c}\text { Reference } \\
\text { year }\end{array}$} & \multirow[t]{2}{*}{$\begin{array}{l}\text { Country } \\
\end{array}$} & \multirow[t]{2}{*}{ Study aim } & \multirow[t]{2}{*}{ Study design } & \multirow{2}{*}{$\begin{array}{c}\text { Study } \\
\text { duration }\end{array}$} & \multirow{2}{*}{$\begin{array}{c}\text { Sample } \\
\text { size }\end{array}$} & \multirow{2}{*}{$\begin{array}{c}\text { Population } \\
\text { group }\end{array}$} & \multicolumn{2}{|c|}{ Tool } & \multicolumn{2}{|c|}{ Perceived tool benefits } & \multirow[t]{2}{*}{ Tool limitations } & \multirow[t]{2}{*}{ Study limitations } & \multirow{2}{*}{$\begin{array}{c}\text { Tool } \\
\text { validity }\end{array}$} \\
\hline & & & & & & & Type & Used & Patient care & Pharmacy services & & & \\
\hline \multirow{9}{*}{$\begin{array}{l}\text { El hajji et } \\
\text { al. }(2015)^{34}\end{array}$} & \multirow[t]{9}{*}{ U.K. } & To develop a & Retrospective & Oct & 806 & In-patients & $\mathrm{NR}$ & $\mathrm{Ph}$ & Can be used to & Enables the prioritization & It is a complex & Small sample size & Validated \\
\hline & & predictive model & chart review & $2003-$ & & who had & & & identify patients & of CPS to optimize & risk assessment & regarding & tool \\
\hline & & to identify & & Sep & & received the & & & at high risk of & patient outcomes & tool as it included & epidemiology & \\
\hline & & patients at high- & & 2008 & & IMM service at & & & readmission, & & score from other & investigations & \\
\hline & & risk of & & & & the hospital & & & mortality and & & algorithms & & \\
\hline & & readmission and & & & & & & & longer hospital & & & & \\
\hline & & post-discharge & & & & & & & stay & & & & \\
\hline & & mortality to & & & & & & & & & & & \\
\hline & & prioritize CPS & & & & & & & & & & & \\
\hline
\end{tabular}




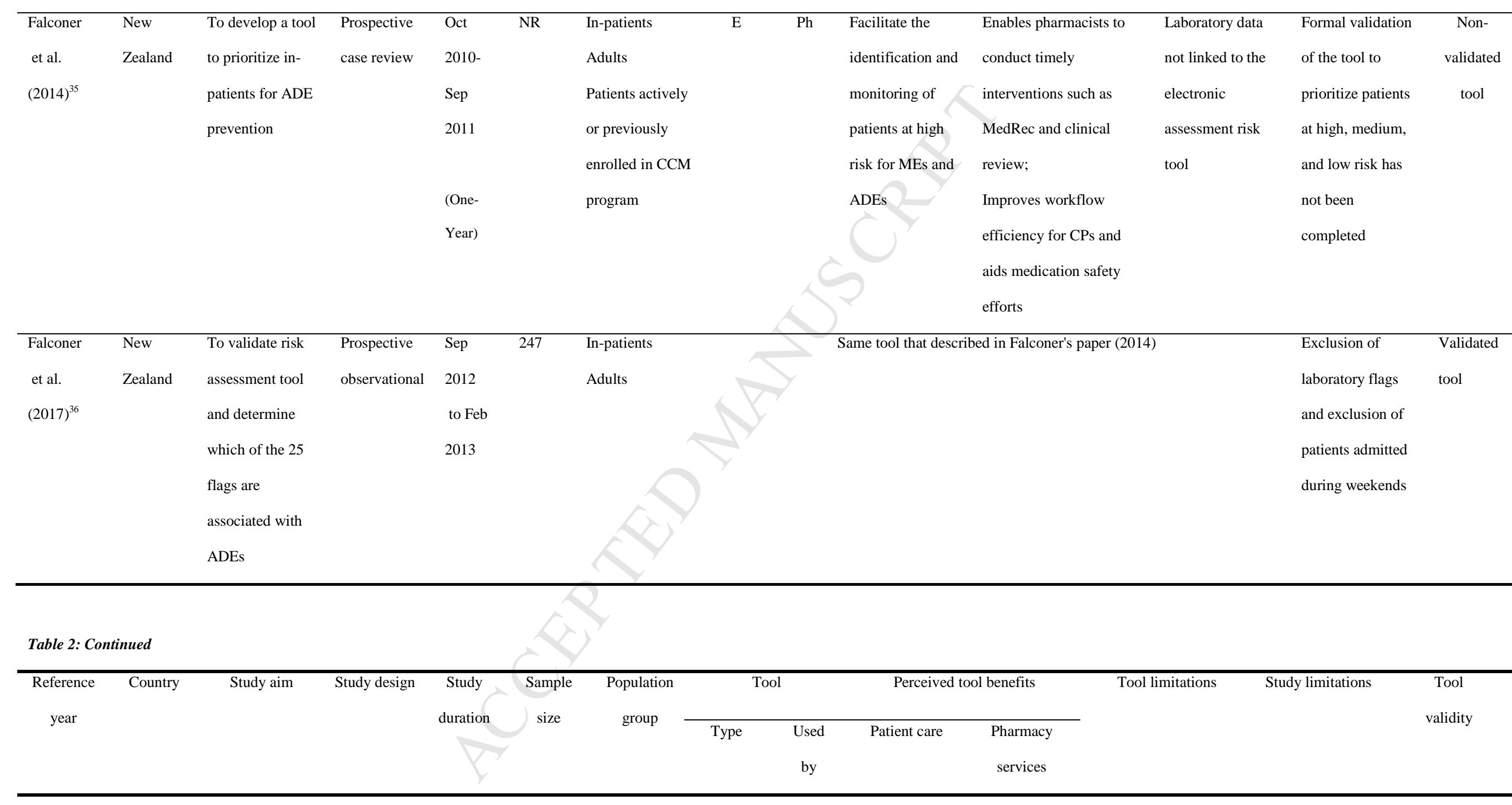




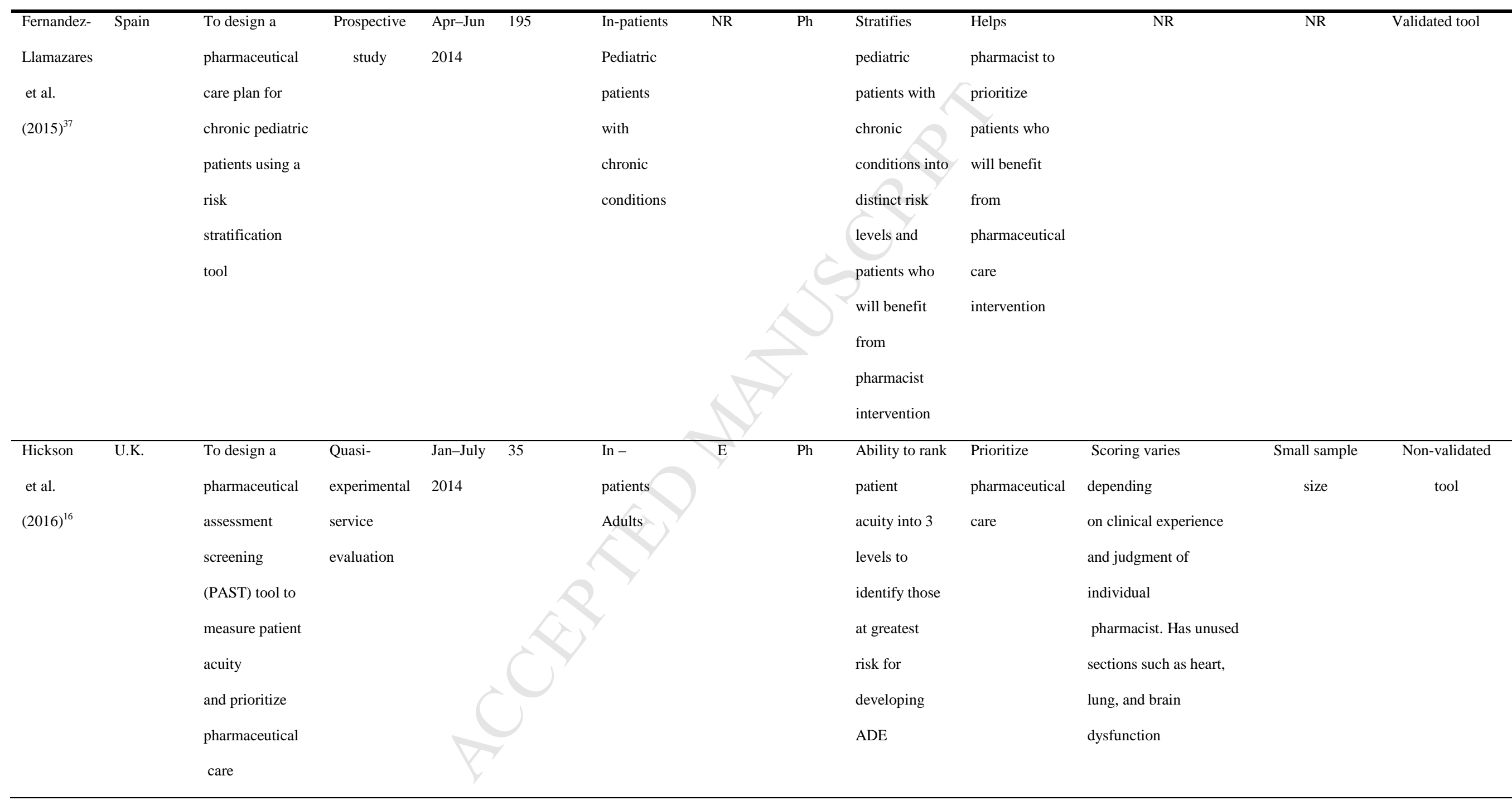




\begin{tabular}{|c|c|c|c|c|c|c|c|c|c|c|c|c|}
\hline $\begin{array}{ll}\text { Jeon et al. } & \text { U.S. } \\
(2017)^{38} & \end{array}$ & $\begin{array}{l}\text { To develop } \\
\text { EHR-based } \\
\text { prediction } \\
\text { model (C-score) } \\
\text { for ranking } \\
\text { hospitalized } \\
\text { patients based } \\
\text { on preventable } \\
\text { ADEs }\end{array}$ & $\begin{array}{l}\text { Systematic } \\
\text { literature } \\
\text { review and } \\
\text { survey }\end{array}$ & $\begin{array}{l}\text { Survey } \\
\text { (12 days) }\end{array}$ & $\begin{array}{l}7391 \\
\text { ASHP } \\
\text { members } \\
\text { and } 21 \\
\text { preventable } \\
\text { ADEs }\end{array}$ & $\begin{array}{l}\text { ASHP } \\
\text { members }\end{array}$ & $\mathrm{E}$ & $\mathrm{Ph}$ & $\begin{array}{l}\text { May improve } \\
\text { patient safety } \\
\text { by identifying } \\
\text { preventable } \\
\text { ADEs }\end{array}$ & $\begin{array}{l}\text { Can prioritize } \\
\text { patients for } \\
\text { pharmacist } \\
\text { medication } \\
\text { therapy } \\
\text { management } \\
\text { services }\end{array}$ & NR & $\begin{array}{l}\text { The evaluation of } \\
\text { the tool was } \\
\text { limited by very } \\
\text { low response rate }\end{array}$ & . \\
\hline
\end{tabular}

168

169 Table 2: Continued

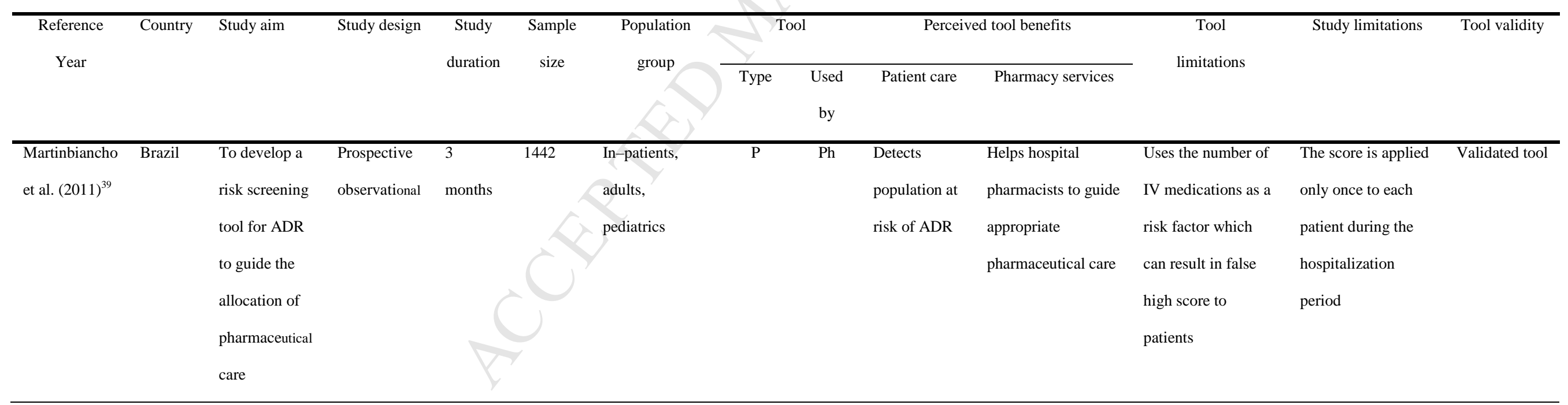




\begin{tabular}{|c|c|c|c|c|c|c|c|c|c|c|c|c|c|}
\hline $\begin{array}{l}\text { Mondoloni } \\
\text { et al. }(2016)^{40}\end{array}$ & France & $\begin{array}{l}\text { To develop a } \\
\text { medication } \\
\text { reconciliation } \\
\text { activity for } \\
\text { patients at the } \\
\text { greatest risk of } \\
\text { MEs }\end{array}$ & $\begin{array}{c}\text { Prospective } \\
\text { study }\end{array}$ & $\begin{array}{c}2 \\
\text { months }\end{array}$ & 82 & $\begin{array}{l}\text { In-patients. } \\
\text { All patients } \\
\text { hospitalized } \\
\text { through the } \\
\text { emergency } \\
\text { room }\end{array}$ & $\mathrm{P}$ & $\mathrm{Ph}$ & $\begin{array}{l}\text { Helps to } \\
\text { identify } \\
\text { patients at the } \\
\text { greatest risk } \\
\text { of medication } \\
\text { errors }\end{array}$ & $\begin{array}{l}\text { Enables the } \\
\text { pharmacist to act } \\
\text { quickly to identify } \\
\text { and correct the } \\
\text { errors and reduce } \\
\text { the pharmacist's } \\
\text { workload }\end{array}$ & NR & $\begin{array}{l}\text { Insufficient } \\
\text { collection of risk } \\
\text { factors by } \\
\text { emergency } \\
\text { prescribers }\end{array}$ & NR \\
\hline $\begin{array}{l}\text { Mott et al. } \\
(2016)^{41}\end{array}$ & U.K. & $\begin{array}{l}\text { To identify } \\
\text { patients at } \\
\text { greater need } \\
\text { for } \mathrm{PhC} \text { and } \\
\text { the level of } \\
\text { pharmacist } \\
\text { experience } \\
\text { required }\end{array}$ & $\begin{array}{l}\text { Prospective } \\
\text { observational } \\
\text { study }\end{array}$ & $\begin{array}{l}3 \\
\text { months }\end{array}$ & 245 & $\begin{array}{l}\text { In-patients. } \\
\text { Pediatric } \\
\text { patients }\end{array}$ & $P$ & $\mathrm{Ph}$ & $\begin{array}{l}\text { Assists in } \\
\text { identifying } \\
\text { patients in } \\
\text { need of a } \\
\text { greater level } \\
\text { of care }\end{array}$ & $\begin{array}{l}\text { Optimizes } \\
\text { pharmaceutical care } \\
\text { by directing patients } \\
\text { to the most } \\
\text { appropriate } \\
\text { pharmacist }\end{array}$ & $\begin{array}{l}\text { Developed and } \\
\text { validated in a single } \\
\text { pediatric hospital } \\
\text { limiting its } \\
\text { applicability to other } \\
\text { patients }\end{array}$ & NR & NR \\
\hline $\begin{array}{l}\text { Mullan and } \\
\text { Jennings } \\
(2013)^{42}\end{array}$ & U.K. & $\begin{array}{l}\text { To assess the } \\
\text { use of } \\
\text { individual } \\
\text { features, } \\
\text { prioritization, } \\
\text { report } \\
\text { generation and } \\
\text { pharmacist } \\
\text { views on the }\end{array}$ & $\begin{array}{l}\text { Survey } \\
\text { questionnaire }\end{array}$ & $\begin{array}{l}\text { Feb- } \\
\text { Mar } \\
2013\end{array}$ & 29 & $\begin{array}{l}\text { All pharmacists } \\
\text { covering EP } \\
\text { wards }\end{array}$ & E & $\mathrm{Ph}$ & $\begin{array}{l}\text { Enables } \\
\text { activities that } \\
\text { improve } \\
\text { patient safety } \\
\text { such MedRec, } \\
\text { drug } \\
\text { interventions } \\
\text { and } \\
\text { biochemistry }\end{array}$ & $\begin{array}{l}\text { Improves the time } \\
\text { utilization by } \\
\text { pharmacist and } \\
\text { decreases workload; } \\
\text { Helps pharmacists to } \\
\text { prioritize high-risk } \\
\text { patients }\end{array}$ & $\begin{array}{l}\text { The new report is } \\
\text { underused, } \\
\text { presenting potential } \\
\text { problems such as } \\
\text { missed doses, and } \\
\text { thus requires follow- } \\
\text { up studies to } \\
\text { identify whether } \\
\text { there are any }\end{array}$ & NR & NR \\
\hline
\end{tabular}


170

$171 \quad$ Table 2: Continued

\begin{tabular}{|c|c|c|c|c|c|c|c|c|c|c|c|c|c|}
\hline \multirow{2}{*}{$\begin{array}{c}\text { Reference } \\
\text { year }\end{array}$} & \multirow[t]{2}{*}{ Country } & \multirow[t]{2}{*}{ Study aim } & \multirow[t]{2}{*}{ Study design } & \multirow{2}{*}{$\begin{array}{c}\text { Study } \\
\text { duration }\end{array}$} & \multirow{2}{*}{$\begin{array}{c}\text { Sample } \\
\text { size }\end{array}$} & \multirow{2}{*}{$\begin{array}{l}\text { Population } \\
\text { group }\end{array}$} & \multicolumn{2}{|c|}{ Tool } & \multicolumn{2}{|c|}{ Perceived tool benefits } & \multirow[t]{2}{*}{ Tool limitations } & \multirow{2}{*}{$\begin{array}{c}\text { Study } \\
\text { limitations }\end{array}$} & \multirow{2}{*}{$\begin{array}{c}\text { Tool } \\
\text { validity }\end{array}$} \\
\hline & & & & & & & Type & $\begin{array}{l}\text { Used } \\
\text { by }\end{array}$ & Patient care & $\begin{array}{l}\text { Pharmacy } \\
\text { services }\end{array}$ & & & \\
\hline $\begin{array}{l}\text { Munday and } \\
\text { Forrest } \\
(2016)^{43}\end{array}$ & U.K. & $\begin{array}{l}\text { To describe a system } \\
\text { prioritizing patients } \\
\text { based on } \\
\text { pharmaceutical care } \\
\text { needs (clinical triage } \\
\text { and referral system) }\end{array}$ & $\begin{array}{c}\text { Descriptivest } \\
\text { udy }\end{array}$ & NR & NR & $\begin{array}{l}\text { In-patients } \\
\text { All acute } \\
\text { care } \\
\text { inpatients }\end{array}$ & E & $\mathrm{Ph}$ & $\begin{array}{l}\text { Improves patient } \\
\text { prioritization and quality } \\
\text { of service, equity of } \\
\text { patient care and patient } \\
\text { safety }\end{array}$ & $\begin{array}{l}\text { Enables } \\
\text { pharmacists to } \\
\text { prioritize patients } \\
\text { for } \mathrm{PhC} \text { and } \\
\text { improves } \\
\text { workflow }\end{array}$ & $\begin{array}{l}\text { The use of triage tool } \\
\text { is used together with } \\
\text { the professional } \\
\text { judgement of the } \\
\text { pharmacist may vary } \\
\text { outcomes }\end{array}$ & $\begin{array}{l}\text { Review } \\
\text { article }\end{array}$ & $\begin{array}{c}\text { Validated } \\
\text { tool }\end{array}$ \\
\hline $\begin{array}{l}\text { Nguyen et } \\
\text { al. }(2017)^{44}\end{array}$ & France & $\begin{array}{l}\text { To develop a } \\
\text { predictive model to } \\
\text { identify high-risk } \\
\text { patients and the } \\
\text { impact on clinical } \\
\text { decisions (MEs) }\end{array}$ & $\begin{array}{c}\text { Prospective } \\
\text { cohort }\end{array}$ & $\begin{array}{l}\text { March- } \\
\text { April } \\
2014\end{array}$ & 1408 & $\begin{array}{l}\text { In-patients } \\
\text { Adults } \\
(\geq 17 \text { yrs) }\end{array}$ & $\mathrm{E}$ & $\mathrm{Ph}$ & $\begin{array}{l}\text { Predicts occurrence of } \\
\text { MEs to guide } \\
\text { intervention for high-risk } \\
\text { patients }\end{array}$ & $\begin{array}{l}\text { Improves } \\
\text { pharmacist } \\
\text { human resource } \\
\text { allocation and } \\
\text { subsequent } \\
\text { patient safety }\end{array}$ & $\begin{array}{l}\text { Tool excluded } \\
\text { biological markers, } \\
\text { diagnostic categories, } \\
\text { and co-morbidities } \\
\text { with a high potential } \\
\text { for ADRs }\end{array}$ & $\begin{array}{l}\text { Non-harmful } \\
\text { MEs were not } \\
\text { included }\end{array}$ & $\begin{array}{c}\text { Validated } \\
\text { tool }\end{array}$ \\
\hline
\end{tabular}




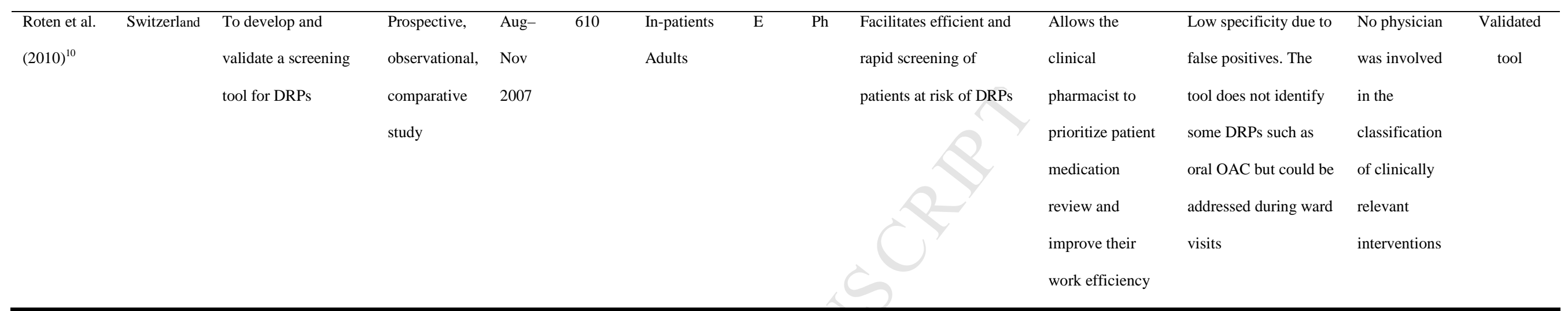

173 Table 2: Continued

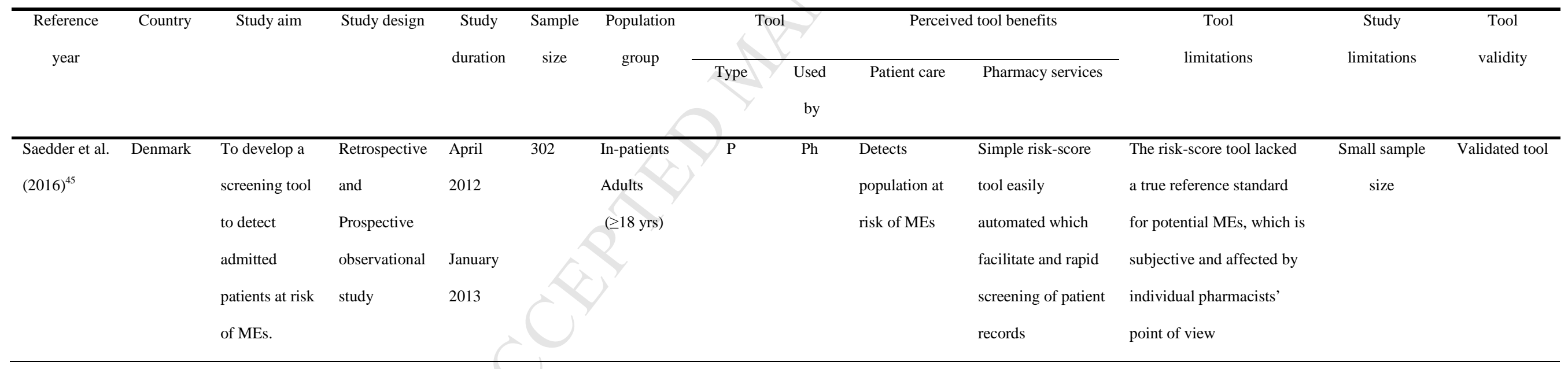




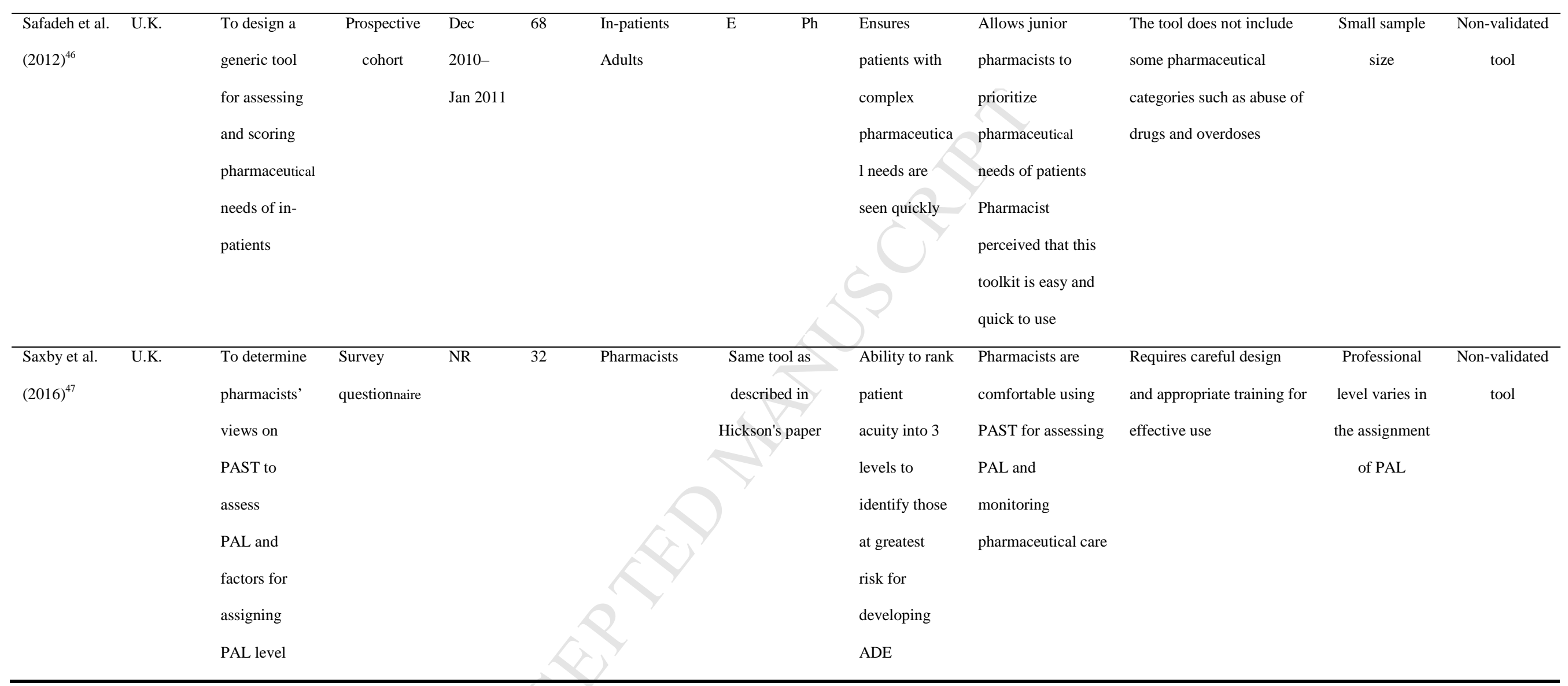

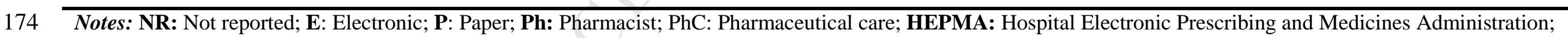

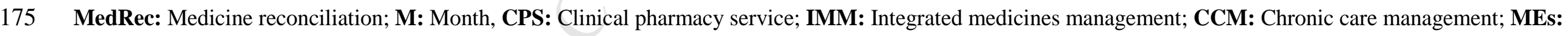

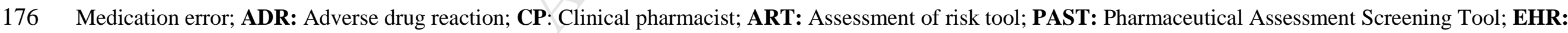

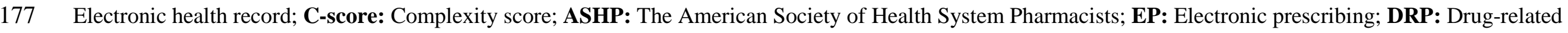

178 problem; OAC: Oral anticoagulant; CPOE: Computerized physician order entry; PAL: Patient acuity level. 
179 Regarding quality assessment, 10 studies were identified as high quality, 4 as medium quality

180 and 5 as low quality. Despite some being of lower quality than others, all studies were

181 relevant to the research and were therefore included in this review. None of the reviewed

182 papers were of very poor quality. The number of scoring tools was lower than the number of

183 studies because the pharmaceutical assessment screening tool (PAST) ${ }^{16}$ and the assessment

184 risk tool (ART) ${ }^{35}$ were each applied in two different studies. ${ }^{36,47}$ Where PAST, a tool for

185 measuring patient acuity and prioritizing pharmaceutical care, was designed in an initial

186 study, ${ }^{16}$ a subsequent study ${ }^{47}$ attempted to establish pharmacists' attitudes toward the tool.

187 Similarly, an initial study ${ }^{35}$ described the development of the ART for prioritizing in-patients

188 for the prevention of ADEs, and a follow-up as followed by study ${ }^{36}$ which validated the same

189 tool. Most (14/17) of the tools were published in the last 5 years, revealing an increased

190 interest in the development of risk assessment tools globally. The studies were conducted in

191 diverse regions of the world. More studies regarding the development of priority tools were

192 conducted in Europe $(\mathrm{n}=14 ; 73 \%)^{10,16,32-34,37,40-47}$ with the U.K. leading with $9(47 \%)$

193 studies. ${ }^{16,32-34,41-43,46,47}$ Table 2 shows the countries which have developed and published a

194 tool. 
195 The studies adopted various research designs. Most $(\mathrm{n}=11 ; 58 \%)$ were prospective

196 observational studies, either single center or multi-center. ${ }^{10,32,35-37,39-41,44-46}$ The remaining

197 studies were retrospective observational studies, ${ }^{33,34}$ descriptive, ${ }^{31,43}$ systematic review/

198 survey, ${ }^{38}$ quasi-experimental study, ${ }^{16}$ and survey. ${ }^{42,47}$

199 The studies varied because they addressed diverse aims. Most studies (79\%) assessed distinct

200 risk screening tools to assess their ability to identify patients at greatest risk of ADRs, ADEs,

201 or MEs and to guide appropriate pharmaceutical care. ${ }^{10,16,32-41,44-46}$ Two studies assessed their

202 tools, and pharmacists' views of them. ${ }^{42,47}$ Two other studies provided a description of an

203 electronic clinical scoring system to prioritize patients based on pharmaceutical care

204 needs. $^{31,43}$ One study ${ }^{41}$ investigated a tool for assigning patients with a higher need of

205 pharmaceutical care to the appropriate pharmacist.

206 The studies also varied in that they target diverse patient populations applicable to their

207 settings including adult patients $(\geq 18$ years $),{ }^{10,16,35,36,44-46}$ pediatric patients $(<18$ years $),{ }^{37,41}$

208 and obstetric patients. ${ }^{33}$ Furthermore, some studies targeted pharmacists and measured their

209 opinions of existing tools. ${ }^{42,46,47}$ Ten tools were developed electronically, ${ }^{10,16,31,32,35,38,42-44,46}$

2105 in paper form,,$^{33,39-41,45}$ and 2 studies did not state the tool format. ${ }^{34,37}$ Some of the

211 electronic tools used electronic algorithms ${ }^{10,44}$ and some were simply stored

212 electronically. $16,31,32,35,38,42,43,46$

\section{Thematic analysis}

214 Three overarching themes were identified. The positive impact of the risk assessment tools

215 on patient care, the positive impact of the risk assessment tools on the delivery of pharmacy

216 services, and limitations of risk assessment tools. During the thematic analysis of the tool

217 benefits, 2 subthemes for patient care and 4 subthemes for pharmaceutical care were

218 identified (Fig. 2). 
219 The positive impact of the risk assessment tools on patient care

220 The first overarching theme during the thematic analysis was identified as the positive impact

221 of the risk assessment tools on patient care. There was a consensus among the studies that the 222 various assessed risk-scoring tools are beneficial in identifying patients at higher risk of

223 DRPs and consequently in guiding pharmaceutical care. They conveyed several benefits to 224 patients and pharmacists. For patients, 2 subthemes were found across the 19 studies. The 225 first subtheme was concerned with identifying high-risk patients to improve the quality of 226 pharmacy services and improve patient safety. For instance, one tool was capable of ranking 227 patient acuity into 3 levels according to the potential risk of developing ADEs. ${ }^{16}$ Another 228 study $^{45}$ showed that their tool could identify patients at risk of developing MEs. Two 229 studies $^{37,41}$ were able to stratify pediatric patients into diverse risk levels, which could be used 230 to prioritize those patients who would benefit more from pharmacists' interventions. One 231 study $^{34}$ emphasized the ability of their tool to identify patients at high risk of readmission, 232 longer hospital stay, and post discharge mortality.

233 The second subtheme was concerned with identifying high-risk patients who could benefit

234 from medication reconciliation. Medication reconciliation is a formal process of ensuring 235 patients' prescribed medication matches with what they are actually taking. ${ }^{48}$ One study ${ }^{33}$ 236 examined opportunities to improve medication reconciliation, multidisciplinary team

237 coordination, and the prevention of adverse events. Another study ${ }^{31}$ described an electronic 238 clinical scoring system that was able to identify patients who could benefit from detailed 239 medication reconciliations.

\section{The impact of the risk assessment tools on the delivery of pharmacy services}

241 Regarding benefits of the tools for pharmacists and hospital managers, the impact on the 242 provision of pharmacy services was identified as the second overarching theme during the 243 thematic analysis. Four subthemes were identified. The first subtheme was the prioritization 
244 of pharmaceutical care. Nine studies identified the tools as beneficial in prioritizing, guiding

245 and monitoring pharmaceutical care to conduct interventions, such as medication review,

246 medication reconciliation, clinical review, and medication therapy management

247 services. $^{10,16,33,35-39,47}$

248 The second subtheme related to pharmacists' effective time management and workload

249 efficiency. Each study had a distinct approach with some focusing on the improvement of 250 work flow or workload efficiency, ${ }^{31,35,36,40,42,43}$ others focusing on the timely provision of

251 pharmaceutical care, ${ }^{31,32,40}$ and still others on the rapid screening of patient records. ${ }^{45}$

253 The third subtheme was related to optimizing human resources and the allocation of 254 pharmacists to patients, which was based on patient complexity and the expertise of 255 pharmacists. One study ${ }^{44}$ concluded that patient-specific allocation of clinical pharmacy services could be more efficient at the time of patients' hospital admission. Another study ${ }^{41}$ focused on optimizing pharmaceutical care by directing the care of pediatric patients to the most knowledgeable and experienced pharmacist.

259 The fourth subtheme dealt with the attitudes of pharmacists to the tools. The tool described in

260 two studies ${ }^{42,46}$ was perceived by pharmacists as easy and quick to use and pharmacists were 261 comfortable using the PAST for assessing patient acuity level. ${ }^{47}$ It also allowed junior 262 pharmacists to focus on and prioritize the pharmaceutical needs of patients. ${ }^{46}$ Notably, this 263 was the only study referring to the perceptions of junior pharmacists regarding the tool.

\section{Limitations of risk assessment tools}

265 The limitations of risk-scoring tools were identified as the third overarching theme. This 266 theme is related to the design of tools and included the lack of, or incompleteness of, data

267 collection, which was described commonly as a tool limitation. In 2 studies that used the 268 same tool, laboratory data were not linked to the risk assessment tool and excluded patients 
269 who were admitted during weekends. ${ }^{35,36}$ Other tools did not identify some DRPs, ${ }^{10}$ or

270 excluded drug overdose, ${ }^{46}$ biological markers, ${ }^{44}$ diagnostic categories,${ }^{44}$ comorbidity,

271 deranged blood results, ${ }^{32,44}$ and laboratory data. ${ }^{32}$

272 Some limitations were also associated with scoring differences. The authors of 3 studies

273 described that the tools had variations in scoring, depending on clinical experience and

274 judgment of individual pharmacists. ${ }^{16,43,45}$ Two other studies required careful tool design and

275 pharmacists to be trained to use the tool more effectively. ${ }^{16,47}$

276

\section{Tool validity}

278 Regarding validity, 10 out of 17 tools were validated with 2 studies explicitly stating the tools

279 were not validated. However, 5 studies did not state if the tools were validated. Validity was

280 measured by obtaining risk indicators from the literature, and assessing them for inter-

281 observer agreement and agreement with other indicators. ${ }^{39}$ One tool was validated by using

282 an expert group of 3 clinical pharmacists delivering obstetric services, as well as formal input

283 from several academic collaborators. ${ }^{33}$

284 In one study, ${ }^{10}$ the use of the screening tool was compared across 4 clinical pharmacists. The 285 tool was developed in a pre-existing population and validated in a pilot prospective study. ${ }^{45}$

286 In another study, ${ }^{37}$ a pre-test tool was developed and used in 195 patients from 7 hospitals. In

287 the description of an electronic tool, one study ${ }^{43}$ stated that the tool was piloted for triage and

288 referral. In another study, ${ }^{44}$ the data about MEs was fitted and internally validated using a

289 multivariate logistic model to predict occurrence.

290 In the ART, 38 flags were used to in the determination of patient prioritisation. ${ }^{35} \mathrm{~A}$

291 subsequent study of the tool, ${ }^{36}$ identified that 25 flags of the original 38 to be significantly

292 associated with the risk of unintentional MEs. To improve validity, another study ${ }^{34}$ divided a

293 sample of patients $(n=806)$ into a development sample $(n=605)$ and a validation sample $(n$ 
$294=201)$ to create risk-predictive algorithms that would aid in developing a predictive model

295 for identifying patients at high risk of readmission and post-discharge mortality. In another

296 study, 5 patients were assigned to each risk group which were reviewed with the score being

297 assigned based on group's validation of pharmaceutical risk. ${ }^{32}$

\section{Risk factors included in the tools}

299 The risk factors that each tool incorporated to determine acuity were placed into 2 categories:

300 drug related ( 7 risk factors) and patient related (8 risk factors). Two additional categories

301 included other risk factors, which did not fit into either category. The most common risk

302 factors (see Table 3) identified were as follows in descending order of prevalence: high-risk

303 medication (15/17 tools, $88 \%)$, drugs requiring monitoring (15/17 tools, $88 \%)$, polypharmacy

304 (13/17 tools, $76.5 \%)$, use of total parenteral nutrition/nasogastric tube (3/17 tools, $17.6 \%)$,

305 high-cost medication, and number of intravenous and unlicensed medication (1 tool each,

306 6\%). Several definitions of polypharmacy exist, ranging from the prescription of 3 to 6

307 medications or in some cases more. Notably, some studies failed to include the criteria for

308 defining high-risk medication..$^{31,32,37,41,42,46}$ Five tools included various other factors that were

309 not frequently used across all tools, such as cytochrome P450 inducers and inhibitors, blood

310 substitutes, drug induced hemorrhage, and acute kidney injury. They can be found in the

311 "Other" column. The patient related category included other risk factors, which are listed in

312 descending order of prevalence: age (13/17 tools, $76.5 \%)$, renal impairment (9/17 tools, $31353 \%)$, comorbidity (9/17 tools, 53\%), hepatic impairment (5/17 tools, 29\%), reason/time/type

314 of admission (5/17 tools, $29 \%)$, readmission ( $3 / 17$ tools, $18 \%)$, allergies $(3 / 17$ tools, $18 \%)$,

315 and length of stay (2/17 tools, $12 \%)$. Other studies mentioned other factors, such as human

316 immunodeficiency virus, cystic fibrosis, Parkinson's disease, depression, and other factors

317 (Table 3). 
Table 3: A summary of the risk factors

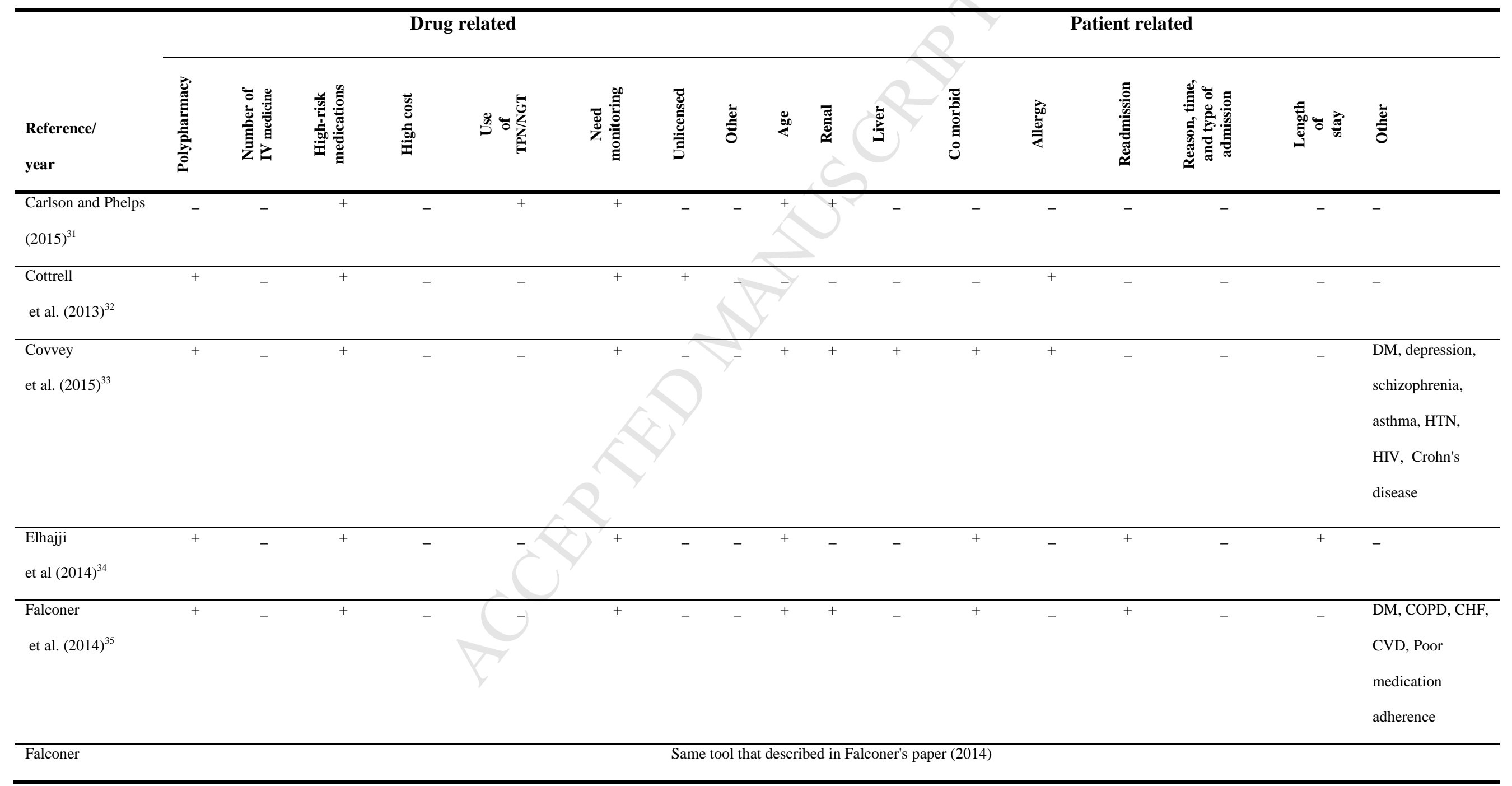


320

321

Table 3: Continued

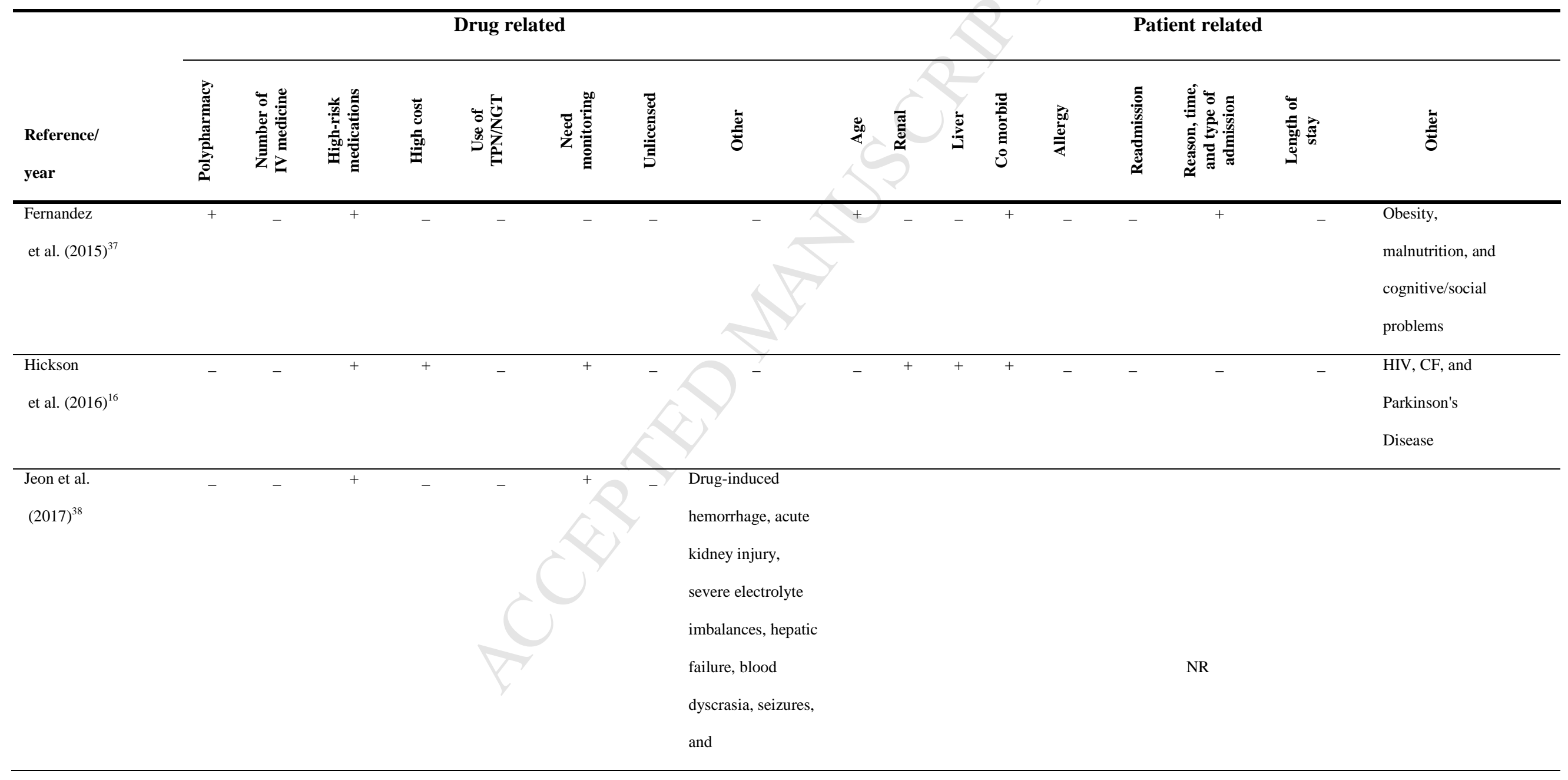




\section{Table 3: Continued}

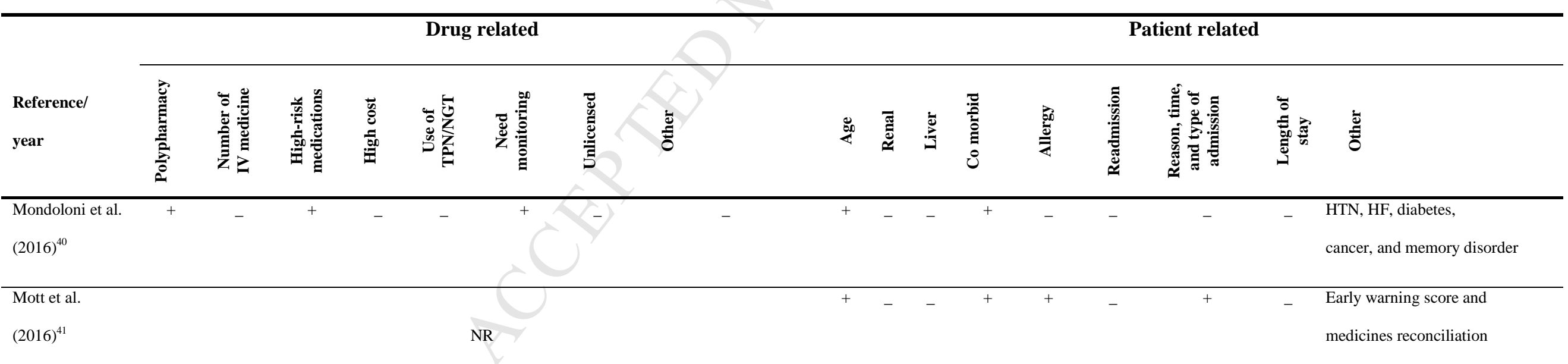




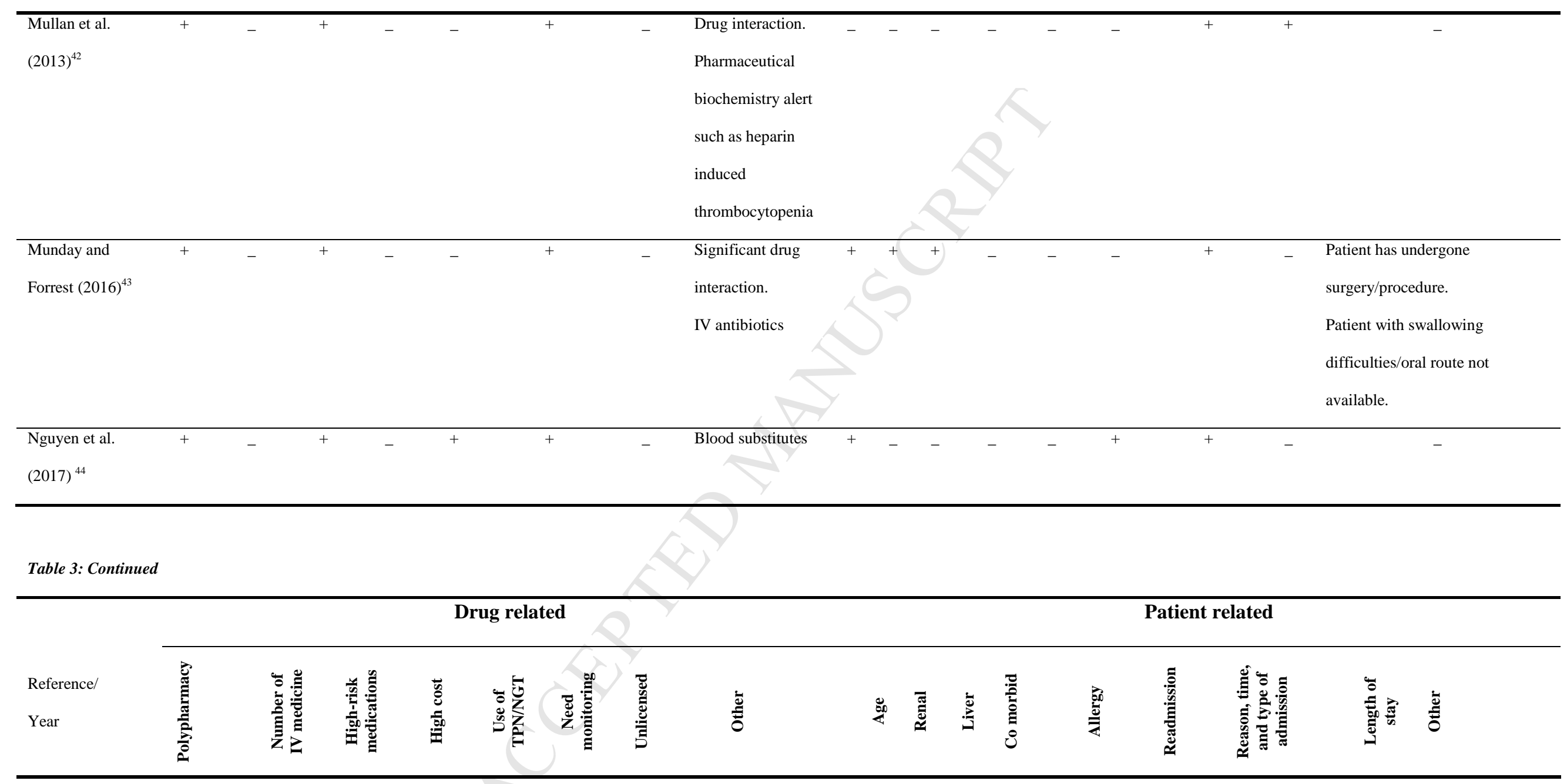




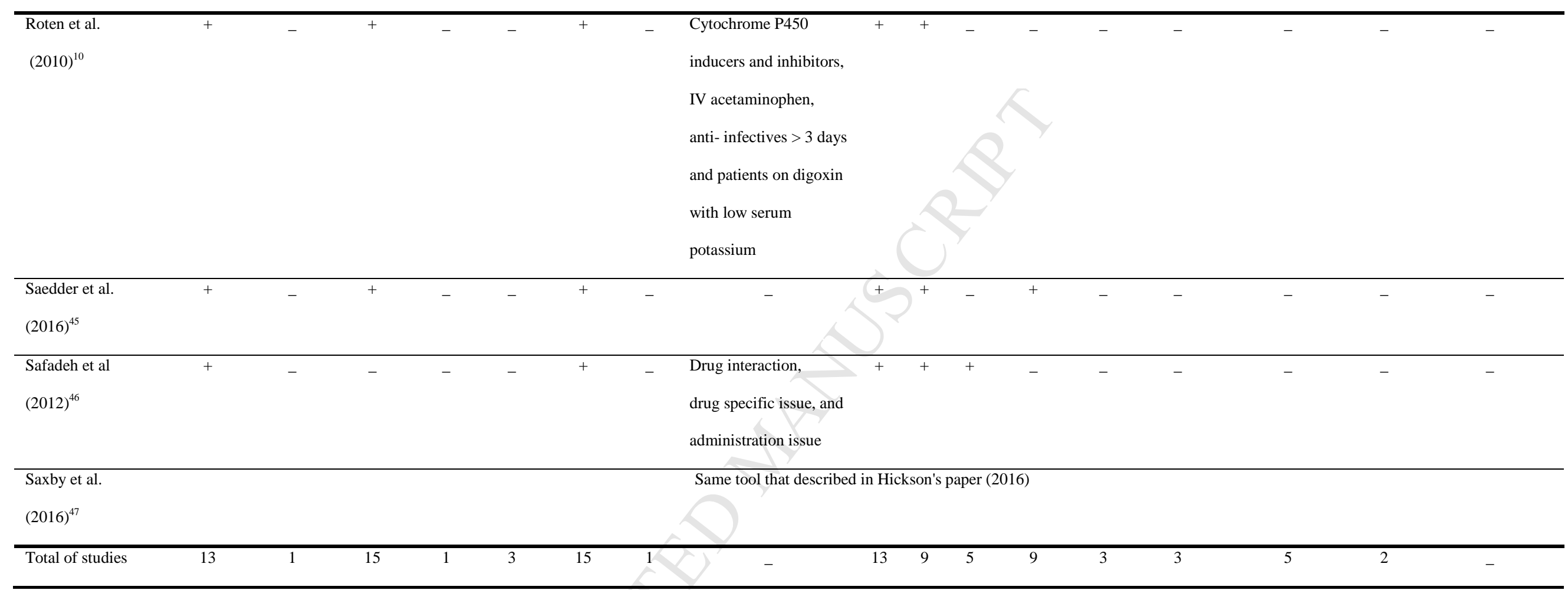

326 +: Risk factors were included in the study; -: Risk factors were not included in the study; IV: Intravenous infusion; TPN: Total parenteral nutrition; NGT:

327 Nasogastric tube; DM: Diabetes mellitus; HTN: Hypertension; HIV: Human immunodeficiency virus; COPD: Chronic obstructive pulmonary disease; CHF:

328 Congestive heart failure; CVD: Cerebrovascular disease; CF: Cystic fibrosis; HF: Heart failure; NR: Not reported. 
329 High-risk drug classes

330 Twelve drug classes were identified in the 19 studies. The summary of drug classes is

331 supplied in appendix C. Some classes of drugs were considered more important than others in

332 the risk assessment tools and are listed in the order of frequency: anticoagulants (14/17 tools,

$33382 \%$ ), cardiovascular medication (12/17 tools, $70.5 \%)$, antiepileptics (12/17 tools, $70.5 \%)$,

334 antimicrobial medication (12/17 tools, 70.5\%), chemotherapy (10/17 tools, 59\%),

335 aminoglycosides (a subgroup of antimicrobials; 10/17 tools, 59\%), immunosuppressants

336 (9/17 tools, 53\%), hypoglycemic/insulin (9/17 tools, 53\%), opiates (9/17 tools, 53\%),

337 antidepressants (7/17 tools, 41\%), anti-inflammatories/NSAIDs (5/17 tools, 29\%), and

338 corticosteroids (3/17 tools, 18\%). Other studies mentioned other medications, such as

339 potassium chloride (IV), eye drops, theophylline, aminophylline, and anti-retrovirals. 


\section{Discussion}

341 The present study is the first review to identify and describe the tools that have been

342 designed and are currently used by clinical pharmacy services to assess patient acuity

343 and complexity. The included studies provide a solid foundation for the reader to

344 enhance their understanding of existing tools that may aid detection of high acuity

345 patients for early and targeted pharmacist interventions. This study focuses

346 exclusively on pharmacist tools and does not reflect on other healthcare professionals,

347 which are outside of the scope of this study.

348 This review revealed a rising interest in the development of risk assessment tools for

349 DRPs to categorize patients as high-risk and to prioritize pharmaceutical care. The

350 UK seems to have placed a greater emphasis on the development of such tools with

351 other countries following suit. It could be postulated that this interest stems from the

352 unique nature of the UK's National Health Service, which is free at the point of use

353 and funded solely via general Government taxation. ${ }^{49}$ Rising numbers of patients and

354 funding pressures within this service have heightened over recent years, and there is a

355 drive to maximize efficiency across the NHS. ${ }^{15,19,20,22}$ Thus, a possible explanation is

356 that this situation increases the pressure on NHS pharmacy departments to prioritize

357 which patients need direct pharmaceutical care.

358 Most tools reviewed in the present study were developed for adults aged older than 17

359 years. In 2 studies, ${ }^{37,41}$ the emphasis was on pediatric patients. No tools have been

360 found that focused on elderly patients within the hospital setting; however, such

361 patients were included in the studies of the general adult population. This is

362 interesting since elderly patients are more likely to have multiple morbidities and

363 associated complex pharmacotherapy, which puts them at risk of adverse outcomes. ${ }^{39}$ 
364 This review highlighted the variation in the complexity and use of algorithms. It also

365 demonstrated that most tools have been designed in an electronic format to ease the

366 screening process and to reduce the amount of time spent by pharmacists on retrieving

367 patient records, as well as reducing the amount of paperwork. ${ }^{31,42,46}$ However, most of

368 the studies that were reviewed failed to explain how the tools operate.

370 The tools include many risk factors. The most prevalent risk factors are high-risk

371 medications - medications requiring monitoring, age, and polypharmacy. Regarding

372 high-risk medications, there was no consistent definition of "high risk" in the

373 reviewed studies. High-risk medication has been defined as harmful to patients ${ }^{15}$;

374 therefore, awareness of their harm to patients, can potentially decrease the

375 hospitalization period, life-threatening conditions, and death by almost $50 \%{ }^{50}$ The

376 four most commonly named drug classes in all the reviewed studies were:

377 anticoagulants, antimicrobials, cardiovascular, and antiepileptic drugs. This finding

378 correlates with other studies that have reported similar drug classes to be associated

379 with hospital setting problems. ${ }^{50,51}$

380 Furthermore, this review found polypharmacy is commonly considered a risk factor

381 for requiring pharmaceutical care. This finding was supported by several studies that

382 concluded that polypharmacy can lead to negative health outcomes and frequent

383 hospitalization by influencing DRPs. ${ }^{52-55}$ Polypharmacy is particularly prevalent

384 among the elderly population who are more likely to have multiple conditions. ${ }^{10}$

385 Hospital length of stay is also considered a key indicator of resource usage in

386 hospitals. ${ }^{56}$ Length of stay and hospital costs are often correlated. ${ }^{57}$ Only 2 reviewed

387 tools included length of stay as a risk factor. The reason for this was not stated in the 
388 other studies. One of the reasons could be some tools were used at the beginning of

389 hospital admission.

390 The tools were reported to have clear benefits regarding patient care and pharmacy

391 services delivery. However, some of these benefits are the perceptions of those using

392 and implementing the tools, and were not necessarily confirmed by robust data to

393 verify these perceptions. The tools on the whole aim to improve pharmacists'

394 workload and help them work more efficiently. This goal seems to have been

395 achieved in other healthcare settings. For instance, decision makers can already use

396 the acuity-scoring tools to assist in assigning the appropriately experienced and

397 knowledgeable nurse to the right patient. ${ }^{58,59}$ This ensures a more consistent quality of

398 care, decreases mortality rates, improves outcomes, and shortens hospital stays. ${ }^{58}$ The

399 tools have reportedly many benefits for both the pharmacy team and patients;

400 inevitably, however, in addition to the tools, clinical experience still plays a critical

401 role in pharmacists' decisions regarding outcomes and scoring of patients.

402 Overall, only one publication focused on an assessment tool for patients, which 403 assisted in directing the right pharmacist to the right patient in the pediatric 404 department; however, there was insufficient detail provided in this study. ${ }^{41}$ Therefore, 405 more research is needed to explore how tools are used to allocate the most 406 appropriately experienced pharmacist to individual patients in the general inpatient 407 population. Only 3 studies $^{42,46,47}$ explored pharmacists' views of the tools and further 408 work is necessary to gain a more complete picture of the impact of tools on the 409 individual pharmacist and their own acquisition of knowledge and skills.

410 The safety of patients has been significantly improved by providing clinical 411 pharmacist services among diverse hospital services. ${ }^{12}$ Clinical pharmacy services 412 have a positive impact on patients' outcomes by decreasing MEs, ADEs, and 
413 ADRs. ${ }^{12,51,60}$ Risk assessment tools could be of benefit to patients as such tools

414 provide early indicators to detect MEs. Interestingly, the impact of tools on patients

415 and on MEs and ADEs has not been demonstrated in any of the studies. Hence, there

416 is a need for more research that investigates the impact of the tools on patient care

417 quality and patient safety.

418 When we assessed the quality of the studies within the review, some were ranked as 419 low quality but still included. These low ranking studies were abstracts to 420 conferences presenting the assessment tools developed within their hospitals. The 421 papers connected to the abstracts had not been published as full academic papers at 422 the time of the review. The process of academic publication is time-consuming and 423 requires research skills which may form a barrier to the publication of studies 424 undertaken by practising pharmacists who have competing pressures. A recent study 425 of assessment tools used in UK hospital pharmacies indicated that there are a number 426 of tools that have been developed but have not been presented at a congress or 427 meeting. ${ }^{61}$ This leads us to believe that the number of tools is likely to be much higher 428 than those that are formally disseminated through conferences and academic 429 publications.

430 The findings of this review have several implications for pharmacy practice. Those 431 pharmacists who work in clinical practice and are considering adopting or developing 432 their own prioritization tool can take some reassurance that current published tools 433 appear to achieve their aim of successfully targeting clinical pharmacy services to 434 where they are needed most. The tools presented in this review could be adapted or 435 further developed to suit differing clinical and organizational contexts. Lessons that 436 have been learned from exploring the limitations of existing tools include the need for 437 thorough training in the application of tools and extensive consideration of the 
438 inclusion of relevant risk factors to ensure accuracy of detecting high acuity patients.

439 Going forward tool implementation should be monitored, validated and where 440 possible its impact measured to allow for comparison across tools.

$442 \quad$ Limitations

443 Only studies written in English were included in this review, which may mean that 444 noteworthy studies published in other languages were overlooked. The literature 445 search, abstract and full-text screening and quality assessment were performed by 446 only one of the authors (MA). It was difficult to gain fair results when applying 447 Hawker's quality assessment tool, since some abstracts lack the sufficient detail to 448 meet quality assessment criteria. Despite this, it was important to include abstracts if 449 they provided sufficient information about a prioritization tool, due to the limited 450 published literature in this area.

452 Limitations of the included studies are that the tools were not described in full detail; 453 for example, there is a lack of description about what constitutes a high-risk 454 medication. Overall, the published assessment tools are very heterogeneous and differ 455 in aim, structure, content, targeted patient groups, and the extent of validation. As a 456 result comparison across studies and generalizability of the review findings are 457 limited.

\section{Conclusion}

460 This review is the first to provide a summary of currently published tools that will be 461 of use to researchers and pharmacy managers interested in current approaches to 462 identifying those patients are at the greatest risk from DRPs. It is clear that there has 
463 been growing interest in the development of risk assessment tools in recent years.

464 Seventeen published papers have described screening tools designed and used in

465 clinical pharmacy services for the assessment of patients to identify high acuity

466 patients and guide pharmaceutical care. Overall, published assessment tools are

467 heterogeneous, differing in structure, content, targeted patient group, setting, selected

468 outcomes, and extent of validation.

469 Despite this authors were unanimous in that these tools are beneficial in identifying

470 patients perceived to be at higher risk of DRPs and consequently in guiding the

471 provision of pharmaceutical care.

472 Current published studies fail to provide a measurable impact of the tools on patients 473 and their ability to prevent actual harm from medication use. Future studies should 474 attempt to measure patient outcomes and apply similar methods to facilitate 475 comparison across different tools. There is clearly no "gold standard," in terms of 476 pharmacy specific acuity tools and more work is needed to ensure a consistent, high477 quality approach to prioritization of services. 
480 1. Bates DW, Spell N, Cullen DJ, Burdick E, Laird N, Petersen LA, Small SD, Sweitzer

481 BJ, Leape LL. The costs of adverse drug events in hospitalized patients. Adverse Drug Events Prevention Study Group. JAMA. 2018;277:307-311. http://dx.doi.org/10.1001/jama.1997.03540280045032

484 2. Bordet R, Gautier S, Le Louet H, Dupuis B, Caron J. Analysis of the direct cost of adverse drug reactions in hospitalised patients. Eur J Clin Pharmacol. 2001;56:935941. http://dx.doi.org/10.1007/s002280000260

3. Wu C, Bell CM, Wodchis WP. Incidence and economic burden of adverse drug

4. Pirmohamed M, James S, Meakin S, Green C, Scott AK, Walley TJ, Farrar K, Park BK, Breckenridge AM. Adverse drug reactions as cause of admission to hospital: prospective analysis of $18 \quad 820$ patients. BMJ. 2004;329:15-19. http://dx.doi.org/10.1136/bmj.329.7456.15

5. Patel P, Zed PJ. Drug-Related Visits to the Emergency Department: How Big Is the http://dx.doi.org/10.1592/phco.22.11.915.33630

6. Leendertse AJ, Egberts ACG, Stoker LJ, van den Bemt PMLA. Frequency of and Risk Factors for Preventable Medication-Related Hospital Admissions in the Netherlands.

7. Einarson TR. Drug-Related Hospital Admissions. Ann Pharmacother. 1993;27:832840. http://dx.doi.org/10.1177/106002809302700702

504 8. Hepler CD, Strand LM. Opportunities and responsibilities in pharmaceutical care. Am 
506 9. Blix HS, Viktil KK, Moger TA, Reikvam Å. Characteristics of drug-related problems 507 discussed by hospital pharmacists in multidisciplinary teams. Pharm World Sci. $508 \quad$ 2006;28:152-158. http://dx.doi.org/10.1007/s11096-006-9020-z

509 10. Roten I, Marty S, Beney J. Electronic screening of medical records to detect inpatients 510 at risk of drug-related problems. Pharm World Sci. 2010;32:103-107. http://dx.doi.org/10.1007/s11096-009-9352-6

512 11. Bond CA, Raehl CL. Clinical Pharmacy Services, Pharmacy Staffing, and Hospital 513 Mortality Rates.

Pharmacotherapy. 2007;27:481-493. http://dx.doi.org/10.1592/phco.27.4.481

515 12. Kaboli PJ, Hoth AB, McClimon BJ, Schnipper JL. Clinical Pharmacists and Inpatient

Care. Arch Intern Med. 2006;166:955-964. http://dx.doi.org/10.1001/archinte.166.9.955

518 13. de Lyra, Júnior DP, Kheir N, Abriata JP, da Rocha CE, dos Santos CB, Pelá IR.

14. Wang T, Benedict N, Olsen KM, Luan R, Zhu X, Zhou N, Tang H, Yan Y, Peng Y,

Shi L. Effect of critical care pharmacist's intervention on medication errors: A

15. South East England Specialist Pharmacy Services. Prioritising pharmaceutical care systematic review and meta-analysis of observational studies. J Crit Care. 2015;30:1101-1106. http://dx.doi.org/10.1016/j.jcrc.2015.06.018 delivery at ward level: a resource for pharmacy managers working in inpatient settings.

https://www.sps.nhs.uk/wpcontent/uploads/2011/04/Prioritising_pharmaceutical care delivery at ward_level V s1_Apr11_LD.pdf; 2011 Accessed January 11, 2018.

531 16. Hickson RP, Steinke DT, Skitterall C, Williams SD. Evaluation of a pharmaceutical 532 assessment screening tool to measure patient acuity and prioritise pharmaceutical care in a UK hospital. Eur J Hosp Pharm. 2016;24:74-79. 

http://dx.doi.org/10.1136/ejhpharm-2015-000829

535 17. National Health Service England. Transformation of seven day clinical pharmacy services in acute hospitals. https://www.england.nhs.uk/wpcontent/uploads/2016/09/7ds-clinical-pharmacy-acute-hosp.pdf; 2016 Accessed January 11, 2018.

18. National Healt

Service

England. Pharmacy services explained. https://www.nhs.uk/NHSEngland/AboutNHSservices/pharmacists/Pages/pharmacistsa ndchemists.aspx; 2015 Accessed January 11, 2018.

19. The King's Fund. Understanding NHS Financial Pressures. https://www.kingsfund.org.uk/publications/understanding-nhs-financial-pressures; 2017 Accessed January 11, 2018.

20. Suggett E, Marriott J. Risk Factors Associated with the Requirement for Pharmaceutical Intervention in the Hospital Setting: A Systematic Review of the Literature. Drugs - Real World Outcomes. 2016;3:241-263. http://dx.doi.org/10.1007/s40801-016-0083-4

21. Lewis P. Right patient, right time, right pharmacist: the time for clinical prioritisation tools? Eur J Hosp Pharm. 2017;24:314-314. http://dx.doi.org/10.1136/ejhpharm$\underline{2017-001395}$

22. Nuffield Trust. A Decade of Austerity? The Funding Pressures Facing the NHS from 2010/11 to 2021/22. https://www.nuffieldtrust.org.uk/research/a-decade-of-austerity-

556 23. NHS England. How to ensure the right people, with the right skills, are in the right place at the right time. https://www.england.nhs.uk/wp-content/uploads/2013/11/nqb-

559 24. Taylor G, Leversha A, Archer C, Boland C, Dooley MJ, Fowler P, Gordon-Croal S, 
25. Agency for Healthcare Research and Quality. Patient Safety and Quality: An Evidence-Based Handbook for Nurses. https://archive.ahrq.gov/professionals/cliniciansproviders/resources/nursing/resources/nurseshdbk/nurseshdbk.pdf; 2008 Accessed January 11, 2018.

26. Moher D, Liberati A, Tetzlaff J, Altman DG, Group TP. Preferred Reporting Items for Systematic Reviews and Meta-Analyses: The PRISMA Statement. PLoS Med. 2009;6:e1000097. http://dx.doi.org/10.1371/journal.pmed.1000097

27. Gale NK, Heath G, Cameron E, Rashid S, Redwood S. Using the framework method for the analysis of qualitative data in multi-disciplinary health research. BMC Med Res Methodol. 2013;13:117. http://dx.doi.org/10.1186/1471-2288-13-117

28. Hawker S, Payne S, Kerr C, Hardey M, Powell J. Appraising the Evidence: Reviewing Disparate Data Systematically. Qual Health Res. 2002;12:1284-1299. http://dx.doi.org/10.1177/1049732302238251

29. Lorenc T, Petticrew M, Whitehead M, Neary D, Clayton S, Wright K, Thomson H, Cummins S, Sowden A, Renton A. Crime, fear of crime and mental health: synthesis of theory and systematic reviews of interventions and qualitative evidence. 2014;2. http://dx.doi.org/10.3310/phr02020

30. Hedlund N, Beer I, Hoppe-Tichy T, Trbovich P. Systematic evidence review of rates and burden of harm of intravenous admixture drug preparation errors in healthcare settings. BMJ Open. 2017;7:e015912. http://dx.doi.org/10.1136/bmjopen-2017-015912

31. Carlson MK, Phelps PK. Use of an electronic clinical scoring system to prioritize patients' medication-monitoring needs. Am J Heal Pharm. 2015;72:2032-2038. http://dx.doi.org/10.2146/ajhp140827

32. Cottrell R, Caldwell M, Jardine G. Developing and implementing a pharmacy risk screening tool. Hosp Pharm 2013;71. http://www.hospitalpharmacyeurope.com/featured-articles/developing-and- 
implementing-pharmacy-risk-screening-tool

591 33. Covvey JR, Grant J MA. Development of an obstetrics triage tool for clinical pharmacists. $\quad J \quad$ Clin Pharm Ther. 2015;40:539-544. http://dx.doi.org/10.1111/jcpt.12301

594 34. El Hajji FWD, Scullin C, Scott MG, McElnay JC. Enhanced clinical pharmacy service targeting tools: risk-predictive algorithms. J Eval Clin Pract. 2015;21:187-197. http://dx.doi.org/10.1111/jep.12276

35. Falconer N, Nand S, Liow D, Jackson A, Seddon M. Development of an electronic

36. Falconer N, Liow D, Zeng I, Parsotam N, Seddon M, Nand S. Validation of the assessment of risk tool: patient prioritisation technology for clinical pharmacist interventions.

Eur $\quad J \quad$ Hosp

Pharm. 2017;24:320-326. http://dx.doi.org/10.1136/ejhpharm-2016-001165

37. Fernández-Llamazares C, Alonso Pérez L, Cabañas Poy M, Rosa FR, Garrido B,

38. Jeon N, Staley B, Johns T, Lipori GP, Brumback B, Segal R, Winterstein AG.

612 39. Martinbiancho JK, Zuckermann J, Mahmud SDP, dos Santos L, Jacoby T, da Silva D, Vinhas M. Development of Risk Score to Hospitalized Patients for Clinical Pharmacy Rationalization in a High Complexity Hospital. Lat Am J Pharm Am J Pharm.

616 40. Mondoloni P, Renzullo C, Leroy B, Penaud J, Coutet J. Prioritisation of patients for medication reconciliation: Application in patients hospitalised in the emergency unit. 
Eur $J$ Hosp Pharm. 2016;23:A238. http://dx.doi.org/10.1136/ejhpharm-2016$\underline{000875.540}$

620 41. Mott A, Kafka S, Sutherland A. ASSESSING PHARMACEUTICAL CARE NEEDS OF PAEDIATRIC IN-PATIENTS: A TEAM BASED APPROACH. Arch Dis Child. 2016;101:e2. http://dx.doi.org/10.1136/archdischild-2016-311535.4

42. Mullan N, Jennings A. Pharmacists' Use and Views of the Electronic Prescribing Web Portal. Paper presented at GHP/UKCPA $9^{\text {th }}$ National Joint Conference, Harrogate, UK; 2013.

43. Munday A, Forrest R. New Ways Of Pharmacy Team Working Within Acute Hospital Services in NHS Greater Glasgow \& Clyde. J Pharm Manag. 2016;32:84-87.

44. Nguyen T-L, Leguelinel-Blache G, Kinowski J-M, Roux-Marson C, Rougier M, Spence J, Le Manach Y, Landais P. Improving medication safety: Development and

45. Saedder EA, Lisby M, Nielsen LP, Rungby J, Anderson LV, Bonnerup DK, Brock B. impact of a multivariate model-based strategy to target high-risk patients. PLoS One.

46. Safadeh M, Pazik L KR. A baseline assessment of the pharmaceutical needs of adult

47. Saxby KJE, Murdoch R, McGuinness J, Steinke DT, Williams SD. Pharmacists' Detection of Patients at High Risk of Medication Errors: Development and Validation of an Algorithm. Basic Clin Pharmacol Toxicol. 2016;118:143-149. http://dx.doi.org/10.1111/bcpt.12473

48. NHS Foundation Trust. Medicines Reconciliation Guideline G358. http://www.humber.nhs.uk/Downloads/Services/Pharmacy/Guidelines/Medicines reconcilation guideline.pdf; 2012 Accessed January 11, 2018.

645 49. Choices N. About the National Health Service (NHS) in England - NHS Choices. 

https://www.nhs.uk/NHSEngland/thenhs/about/Pages/overview.aspx. Accessed April 21, 2018.

50. Saedder EA, Brock B, Nielsen LP, Bonnerup DK, Lisby M. Identifying high-risk medication: a systematic literature review. Eur J Clin Pharmacol. 2014;70:637-645. http://dx.doi.org/10.1007/s00228-014-1668-z

51. Chisholm-Burns MA, Kim Lee J, Spivey CA, Slack M, Herrier RN, Hall-Lipsy E, Zivin JG, Abraham I, Palmer J, Martin JR, Kramer SS, Kramer T. U US Pharmacists' Effect as Team Members on Patient Care: Systematic Review and Meta-Analyses. Med Care. 2010;48:923-933. http://dx.doi.org/10.1097/MLR.0b013e3181e57962

52. Blix HS, Viktil KK, Reikvam Å, Moger TA, Hjemaas BJ, Pretsch P, Vraalsen TF, Walseth EK. The majority of hospitalised patients have drug-related problems: results from a prospective study in general hospitals. Eur J Clin Pharmacol. 2004;60:651658. http://dx.doi.org/10.1007/s00228-004-0830-4

53. Steinman MA, Seth Landefeld C, Rosenthal GE, Berthenthal D, Sen S, Kaboli PJ. Polypharmacy and Prescribing Quality in Older People. J Am Geriatr Soc. 2006;54:1516-1523. http://dx.doi.org/10.1111/j.1532-5415.2006.00889.x

54. Viktil KK, Blix HS, Moger TA, Reikvam A. Polypharmacy as commonly defined is an indicator of limited value in the assessment of drug-related problems. $\mathrm{Br} J$ Clin Pharmacol. 2007;63:187-195. http://dx.doi.org/10.1111/j.1365-2125.2006.02744.x

55. Alomar MJ. Factors affecting the development of adverse drug reactions (Review article). Saudi Pharm J. 2014;22:83-94. http://dx.doi.org/10.1016/j.jsps.2013.02.003

56. Hansen RN, Pham AT, Böing EA, Lovelace B, Wan GJ, Miller TE. Current Medical Research and Opinion Comparative analysis of length of stay, hospitalization costs, opioid use, and discharge status among spine surgery patients with postoperative pain management including intravenous versus oral acetaminophen. Curr Med Res Opin. 2017;33:943-948. http://dx.doi.org/10.1080/03007995.2017.1297702

57. Freitas A, Silva-Costa T, Lopes F, Garcia-Lema I, Teixeira-Pinto A, Brazdil P, CostaPereira A. Factors influencing hospital high length of stay outliers. BMC Heal Serv 


\section{ACCEPTED MANUSCRIPT}

674

675

676

677

678

679

680

681

682

683 61. Abuzour A, Tully M, Steinke D, Williams S, Lewis P. A descriptive study exploring 684

685

686

687

Res. 2012;12:265. http://dx.doi.org/10.1186/1472-6963-12-265

58. O'Keeffe MO. Practical steps for applying acuity-based staffing. Am Nurse Today. $2016 ; 11: 30-34$.

59. Rischbieth A. Matching nurse skill with patient acuity in the intensive care units: a risk management mandate. J Nurs Manag. 2006;14:397-404. http://dx.doi.org/10.1111/j.1365-2934.2006.00622.x

60. Krähenbühl-Melcher A, Schlienger R, Lampert M, Haschke M, Drewe J, Krähenbühl S. Drug-related problems in hospitals: a review of the recent literature. Drug Saf. 2007;30:379-407. https://doi.org/10.2165/00002018-200730050-00003

the use of pharmaceutical care acuity tools in UK hospitals. Int J Pharm Pract. 2018;26:34-36. https://doi.org/10.1111/ijpp.12442 


\section{Figure captions}

689 Figure 1: Flow diagram of articles included/excluded in the systematic literature review

$690 \quad$ Figure 2: The themes and their subthemes of the tool benefits and limitations

691 


\section{Appendix A: Search strategy}

\section{Appendix A1: Search strategy for Medline:}

\begin{tabular}{|c|c|c|}
\hline$\#$ & Searches & Results \\
\hline 1 & $\begin{array}{l}\text { priorit*.mp. [mp = title, abstract, original title, name of substance word, subject } \\
\text { heading word, keyword heading word, protocol supplementary concept word, rare } \\
\text { disease supplementary concept word, unique identifier, and synonyms] }\end{array}$ & 86838 \\
\hline 2 & triage*.mp. & 17228 \\
\hline 3 & acuity.mp. & 90954 \\
\hline 4 & complex*.mp. & 1273626 \\
\hline 5 & 1 or 2 or 3 or 4 & 1458036 \\
\hline 6 & tool*.mp. & 486875 \\
\hline 7 & scor*.mp. & 697844 \\
\hline 8 & screen*.mp. & 617050 \\
\hline 9 & criteria.mp. & 438374 \\
\hline 10 & scale.mp. & 477813 \\
\hline 11 & classif*.mp. & 469517 \\
\hline 12 & assess*.mp. & 2477446 \\
\hline 13 & measure*.mp. & 2663537 \\
\hline 14 & instrument*.mp. & 235132 \\
\hline 15 & clinical assess* tool*.mp. & 300 \\
\hline 16 & stratif*.mp. & 124843 \\
\hline 17 & software.mp. & 176740 \\
\hline 18 & 6 or 7 or 8 or 9 or 10 or 11 or 12 or 13 or 14 or 15 or 16 or 17 & 6245139 \\
\hline 19 & hospital*.mp. & 1275983 \\
\hline 20 & secondary care.mp. & 4532 \\
\hline 21 & 19 or 20 & 1278712 \\
\hline
\end{tabular}


23 pharmacy.mp.

24 pharmacist*.mp. protocol supplementary concept word, rare disease supplementary 26710 concept word, unique identifier, synonyms]

\begin{tabular}{llc}
\hline 25 & pharmac* service*.mp. & 26496 \\
\hline 26 & hospital pharmac*.mp. & 3461 \\
\hline 27 & clinical pharmac*.mp. & 13611 \\
\hline 28 & clinical pharmac* service*.mp. & 650 \\
\hline 29 & pharmaceutical.mp. & 179014 \\
\hline 30 & 22 or 23 or 24 or 25 or 26 or 27 or 28 or 29 & 233049 \\
\hline 31 & 5 and 18 and 21 and 30 & 719 \\
\hline 32 & 31 & 719 \\
\hline 33 & limit 32 to (English language and year = “1990-current”) & 600
\end{tabular}

695 
696 Appendix A2: Search strategy for Embase:

\# Searches

Results

1 priorit*.mp. [mp = title, abstract, heading word, drug trade name, original title, device 9168508 manufacturer, drug manufacturer, device trade name, keyword, and floating subheading word]

2 triage*.mp.

3 acuity.mp

130033

4 complex*.mp.

1693722

51 or 2 or 3 or 4

10273035

6 tool*.mp.

7 scor*.mp.

1230975

8 screen*.mp.

1095141

9 criteria.mp.

10 scale.mp.

891130

11 classif*.mp.

1002668

12 assess*.mp.

4118394

13 measure*.mp.

3693220

14 instrument*.mp.

576368

15 clinical assess* tool*.mp.

21453

16 stratif*.mp.

17 software.mp.

236855

186 or 7 or 8 or 9 or 10 or 11 or 12 or 13 or 14 or 15 or 16 or 17

19 hospital*.mp.

2113138

20 secondary care.mp.

9034

$21 \quad 19$ or 20

22 pharmaceutical care.mp.

24 pharmacist*.mp. 


\begin{tabular}{llc}
\hline 26 & hospital pharmac*.mp. & 16937 \\
\hline 27 & clinical pharmac*.mp. & 44609 \\
\hline 28 & clinical pharmac* service*.mp. & 1296 \\
\hline 29 & pharmaceutical.mp. & 181080 \\
\hline 30 & 22 or 23 or 24 or 25 or 26 or 27 or 28 or 29 & 346837 \\
\hline 31 & 5 and 18 and 21 and 30 & 6735 \\
\hline 32 & 31 & 6735 \\
\hline 33 & limit 32 to (English language and year $=$ “1990-current") & 6369
\end{tabular}

697 


\section{Appendix A3: Search strategy for International Pharmaceutical Abstracts:}

1 priorit*.mp. [mp = title, subject heading word, registry word, abstract, and trade 1885 name/generic name]

2 triage*.mp. [mp = title, subject heading word, registry word, abstract, and trade 233 name/generic name]

3 acuity.mp. [mp = title, subject heading word, registry word, abstract, and trade 454 name/generic name]

4 complex*.mp. [mp = title, subject heading word, registry word, abstract, and trade 25420 name/generic name]

51 or 2 or 3 or 4 27826

6 tool*.mp. [mp = title, subject heading word, registry word, abstract, and trade 10336 name/generic name]

7 scor*.mp. [mp = title, subject heading word, registry word, abstract, and trade 15498 name/generic name]

8 screen*.mp. [mp = title, subject heading word, registry word, abstract, and trade 12510 name/generic name]

9 criteria.mp. [mp = title, subject heading word, registry word, abstract, and trade 12441 name/generic name]

10 scale.mp. [mp = title, subject heading word, registry word, abstract, and trade 10954 name/generic name]

11 classif*.mp. [mp = title, subject heading word, registry word, abstract, and trade 9518 name/generic name]

12 assess*.mp. [mp = title, subject heading word, registry word, abstract, and trade 63762 name/generic name]

13 measure*.mp. [mp = title, subject heading word, registry word, abstract, and trade 54279 name/generic name]

14 instrument*.mp. [mp = title, subject heading word, registry word, abstract, and trade 3625 name/generic name] 
15 clinical assess* tool ${ }^{*} . \mathrm{mp}$. [mp = title, subject heading word, registry word, abstract, and 4 trade name/generic name]

16 stratif*.mp. [mp = title, subject heading word, registry word, abstract, and trade 2473 name/generic name]

17 software.mp. [mp = title, subject heading word, registry word, abstract, and trade 3687 name/generic name]

186 or 7 or 8 or 9 or 10 or 11 or 12 or 13 or 14 or 15 or 16 or 17

19 hospital*.mp. [mp = title, subject heading word, registry word, abstract, and trade 54586 name/generic name]

20 secondary care.mp. [mp = title, subject heading word, registry word, abstract, and trade 166 name/generic name]

2119 or 20

22 pharmaceutical care.mp. [mp = title, subject heading word, registry word, abstract, and 6664 trade name/generic name]

23 pharmacy.mp. [mp = title, subject heading word, registry word, abstract, and trade 64385 name/generic name]

24 pharmacist*.mp. [mp = title, subject heading word, registry word, abstract, and trade 51415 name/generic name]

25 pharmac* service*.mp. [mp = title, subject heading word, registry word, abstract, and 19273 trade name/generic name]

26 hospital pharmac*.mp. [mp = title, subject heading word, registry word, abstract, and 15956 trade name/generic name]

27 clinical pharmac*.mp. [mp = title, subject heading word, registry word, abstract, and 11158 trade name/generic name]

28 clinical pharmac* service*.mp. [mp = title, subject heading word, registry word, 2771 abstract, and trade name/generic name]

29 pharmaceutical.mp. [mp = title, subject heading word, registry word, abstract, and trade 50974 name/generic name] 


\begin{tabular}{llc}
\hline 31 & 5 and 18 and 21 and 30 & 687 \\
\hline 32 & 31 & 687 \\
\hline 33 & limit 32 to (English language and year = "1990-current") & 618
\end{tabular}

699 
700 Appendix A4: Search strategy for Scopus:

\# Searches

Results

1 TITLE-ABS-KEY (priorit* OR triage* OR acuity OR complex*)

12430249

2 TITLE-ABS-KEY (tool* OR scor* OR screen* OR criteria OR scale OR classif* OR 18978666 assess* OR measure* OR instrument* OR \{clinical assess* tool*\} OR stratif* OR software)

3 TITLE-ABS-KEY (hospital* OR secondary care )

4 TITLE-ABS-KEY (\{pharmaceutical care $\}$ OR pharmacy OR \{pharmac* service* $\} \quad 37178$ OR $\{$ hospital pharmac*\} OR $\{$ clinical pharmac* $\}$ OR $\{$ clinical pharmac* service* $\}$ OR pharmacist* OR pharmaceutical) 


\section{ACCEPTED MANUSCRIPT}

702 Appendix A5: Search strategy for Web of Science:

\# $\quad$ Searches $\quad$ Results

1 priorit* OR triage* OR acuity OR complex* 3409659

2 tool* OR scor* OR screen* OR criteria OR scale OR classif* OR assess* OR 12369905 measure* OR instrument* OR clinical assess* tool* OR stratif* OR software

3 hospital* OR secondary care) $\quad 8866054$

4 pharmaceutical care OR pharmacy OR pharmac* service* OR hospital pharmac* OR 333277 clinical pharmac* OR clinical pharmac* service* OR pharmacist* OR pharmaceutical

$5 \quad 1$ AND 2 AND 3 AND $4 \quad 1188$

6 limit 5 to (English language and year = "1990-current”) 1084

703 
704 Appendix B: Quality assessment of included studies (Hawker's quality assessment tool ${ }^{28}$ )

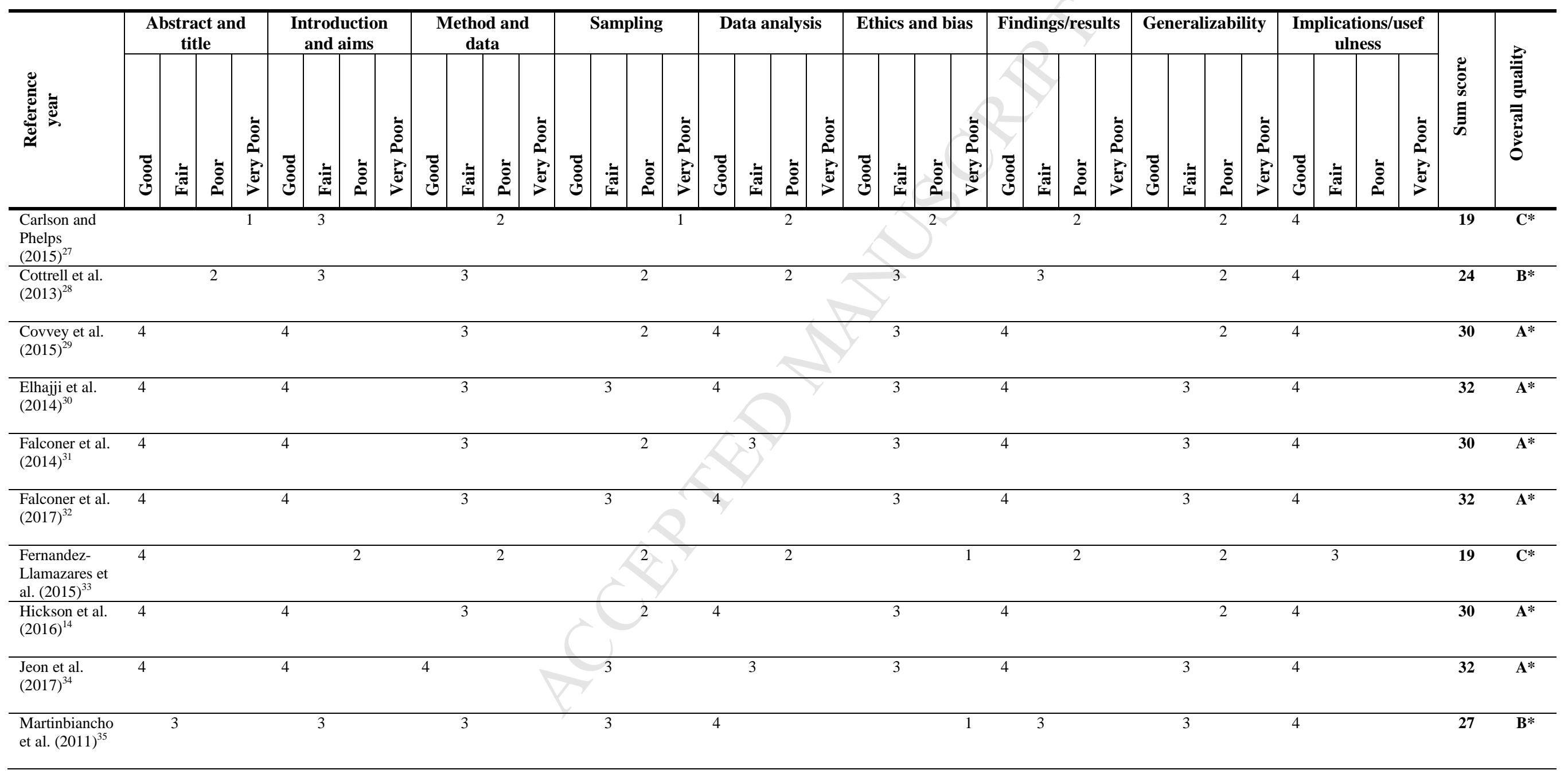




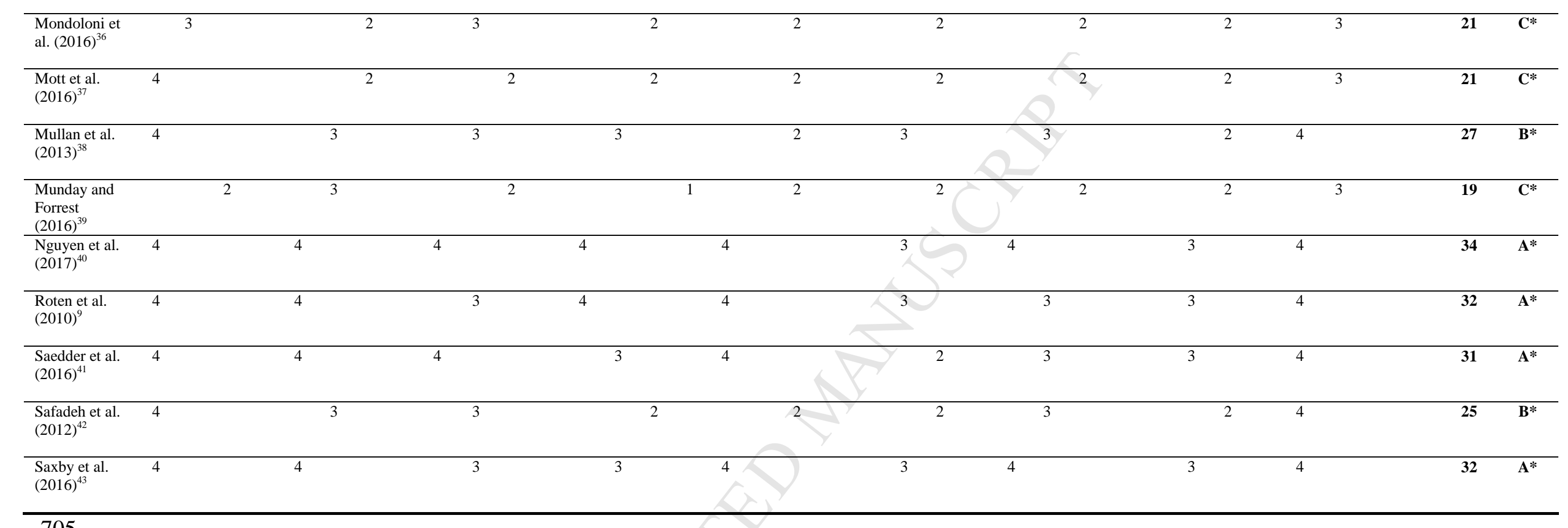

705

$706 *$ High quality (A), 30-36 points

$707 *$ Medium quality (B), 24-29 points

708 *Low quality (C), 9-23 points.

709 
Appendix C: A summary of high-risk drug classes included in tools

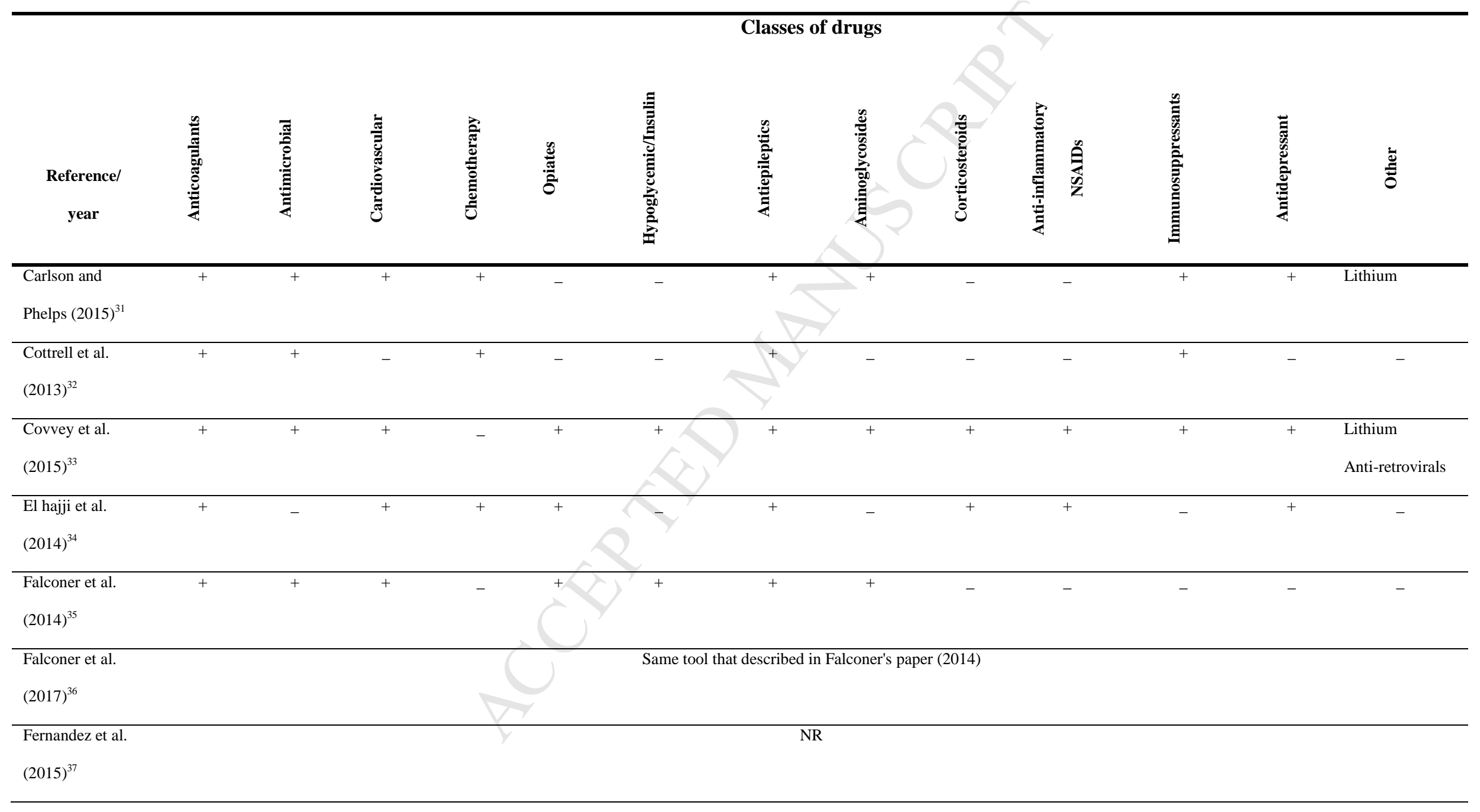




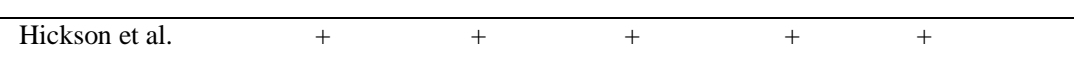

$+$

$+$

$-$

$-$

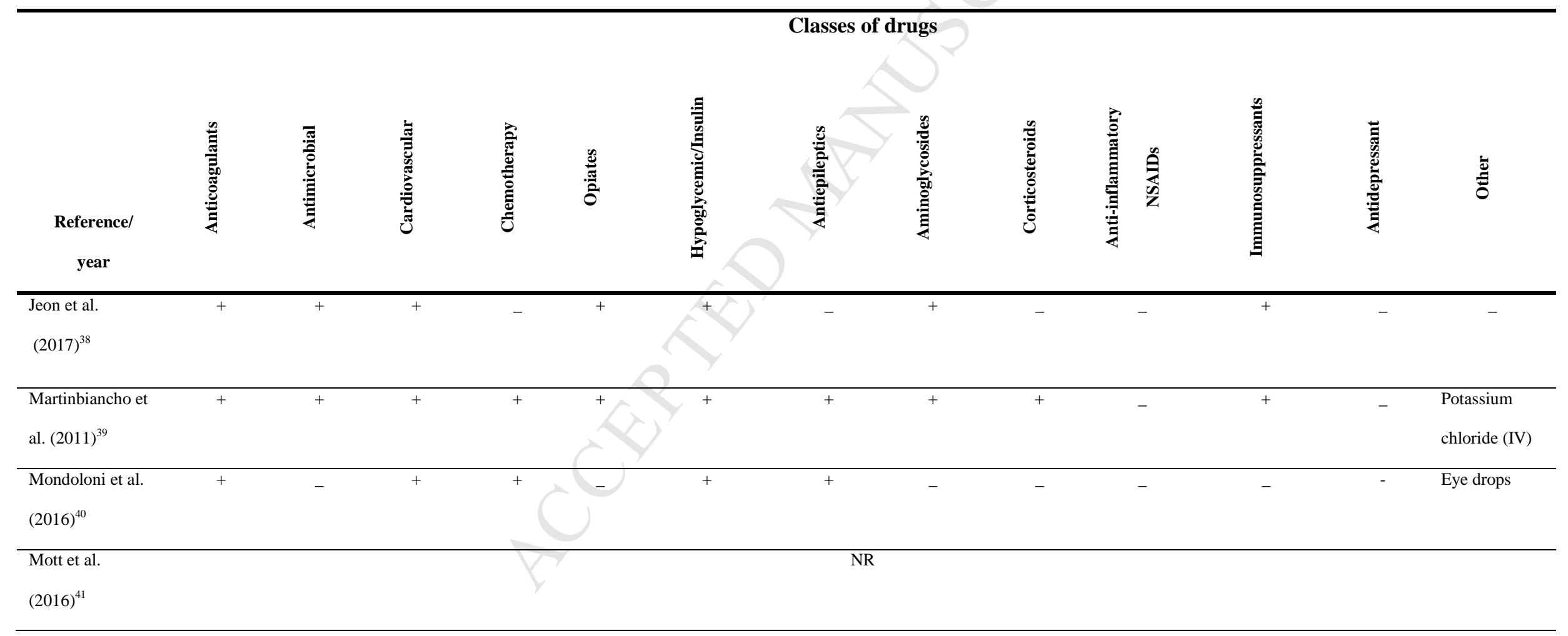




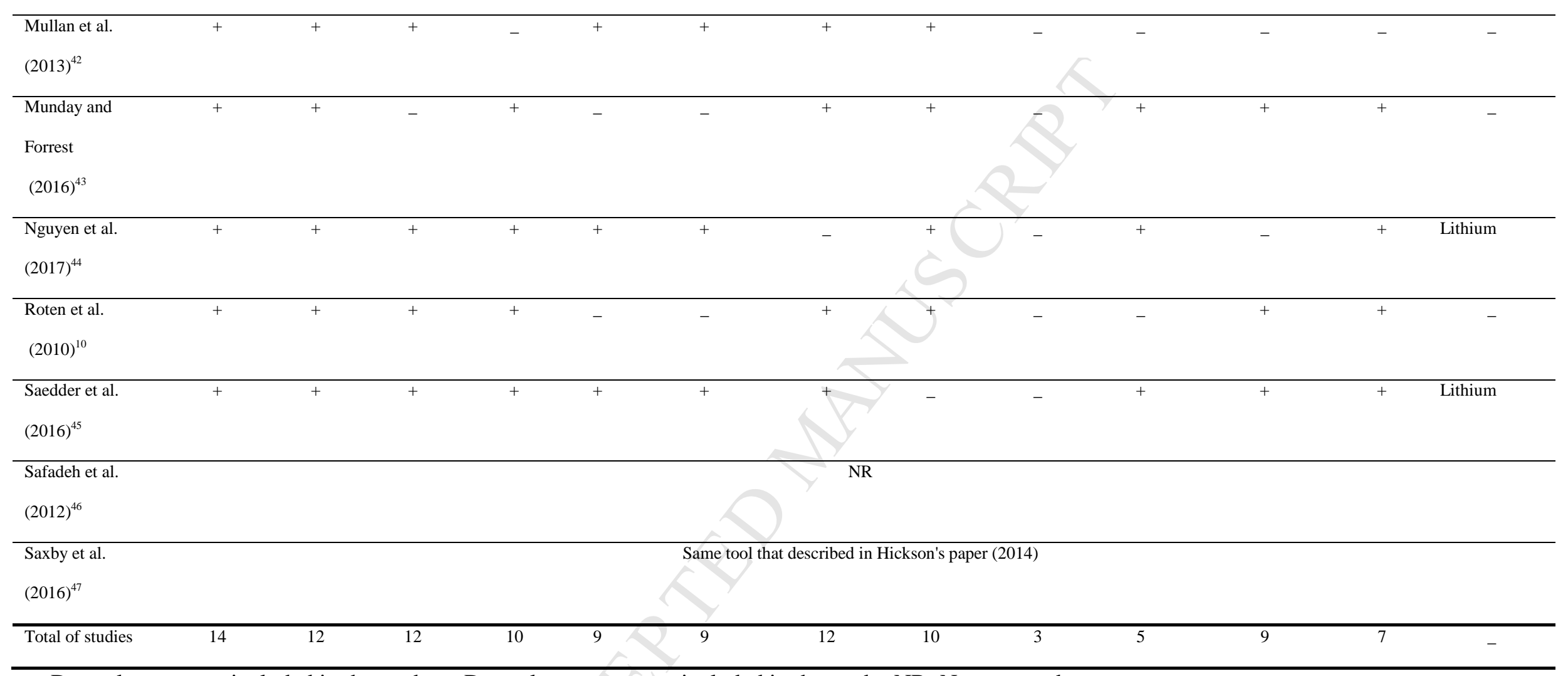

714 

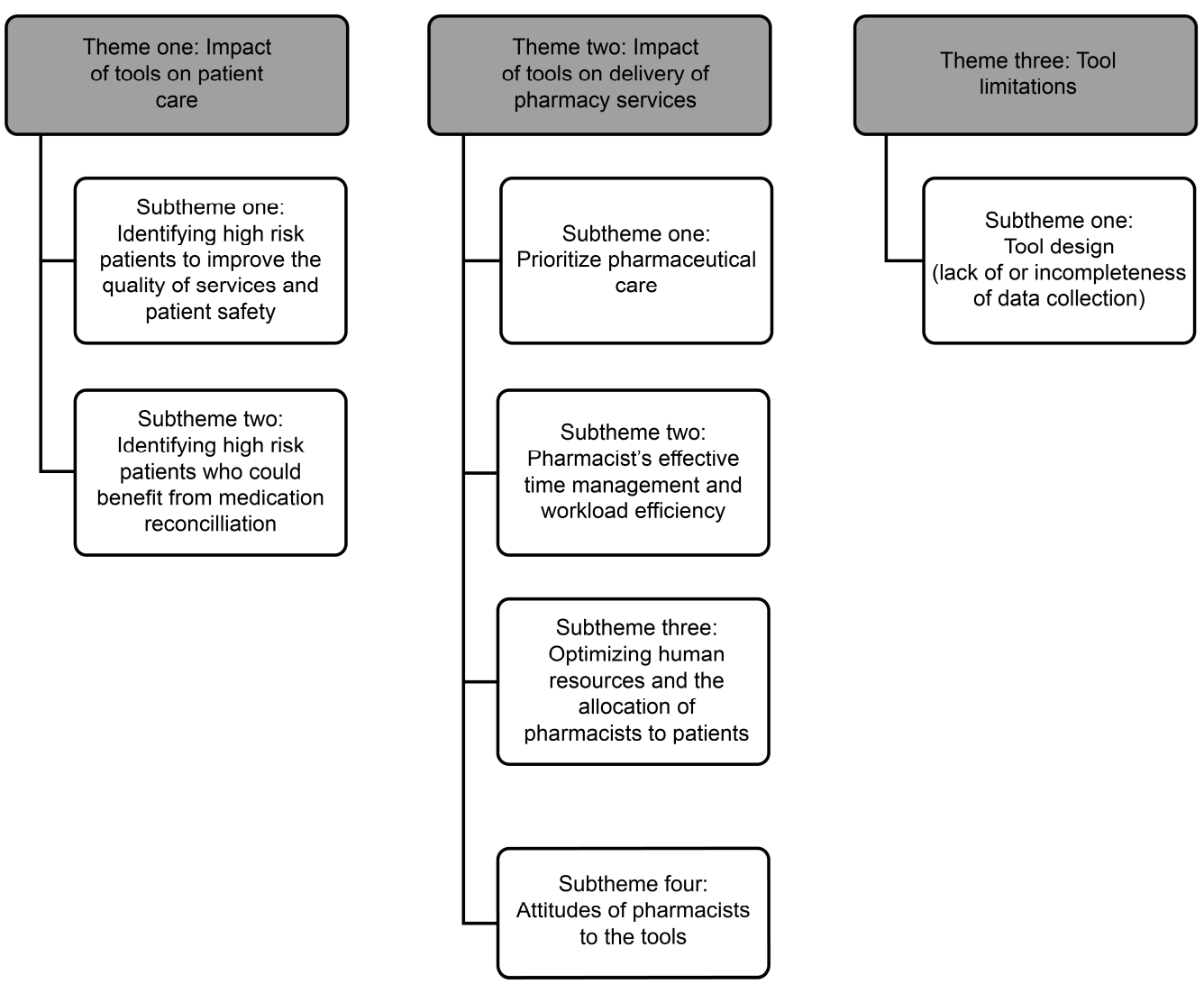
patients who could reconcilliation

Pharmacist's effective

me management and workload efficiency

Subtheme three:

Optimizing human

resources and the

harmacists to patients

Subtheme four:

to the tools 


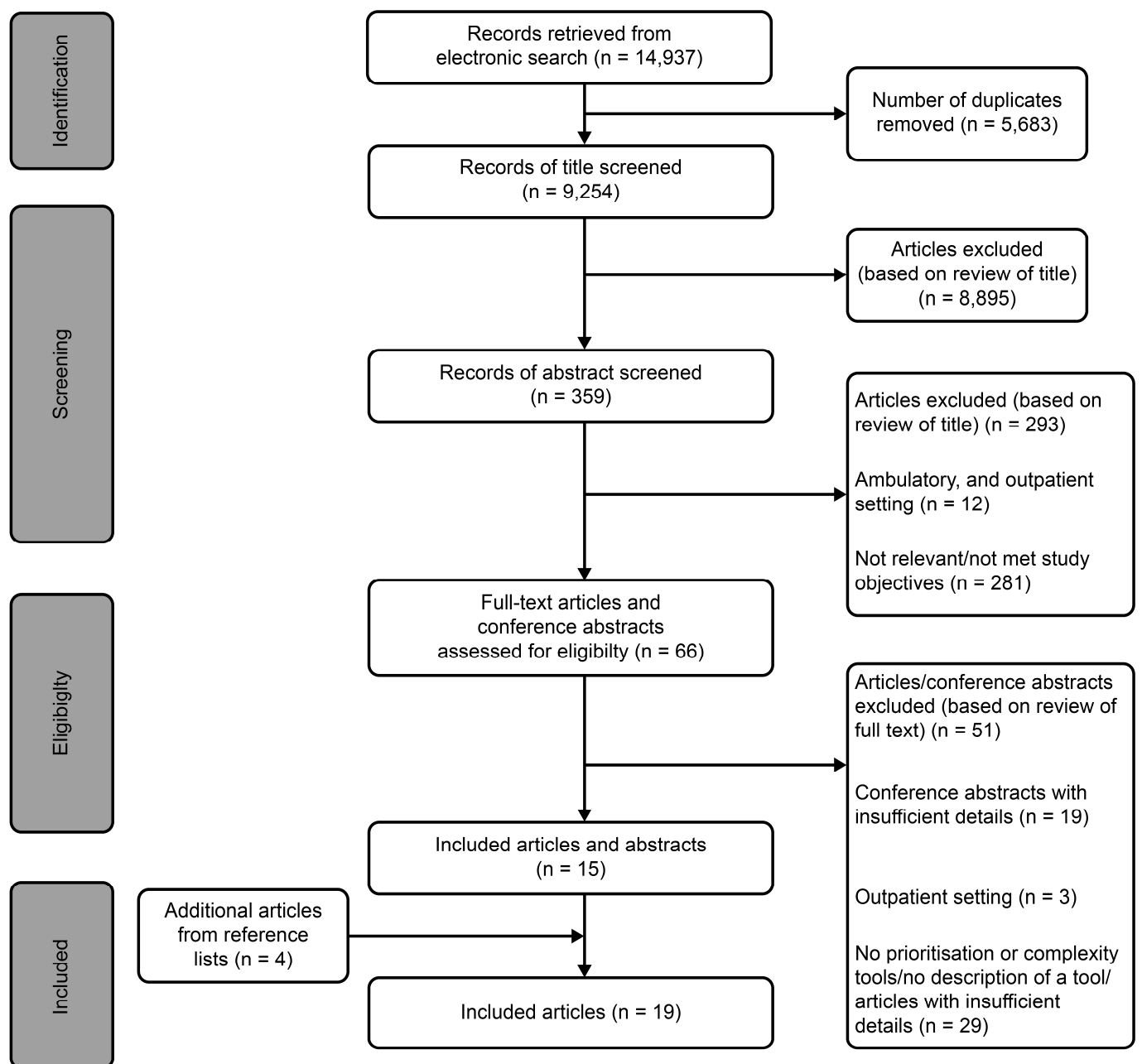

